QUÉBEC NEWS-PRINT MEDIA PORTRAYALS OF IMMIGRANTS DURING THE REASONABLE ACCOMMODATIONS COMMISSION

\author{
By
}

Jacqueline Hall

B.A., Concordia University, 2006

\author{
A Major Research Paper \\ presented to Ryerson University \\ in partial fulfillment of the requirements for the degree of \\ Master of Arts \\ in the program of \\ Immigration and Settlement Studies
}

Toronto, Ontario, Canada, 2010

C) Jacqueline Hall, 2010 


\section{Author's Declaration}

I hereby declare that I am the sole author of this major research paper.

I authorize Ryerson University to lend this paper to other institutions or individuals for the purpose of scholarly research

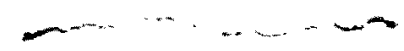

I further authorize Ryerson University to reproduce this paper by photocopying or by other means, in total or in part, at the request of other institutions or individuals for the purpose of scholarly research. 


\title{
QUÉBEC NEWS-PRINT MEDIA PORTRAYALS OF IMMIGRANTS \\ DURING THE REASONABLE ACCOMMODATIONS COMMISSION
}

\author{
Jacqueline Hall \\ Master of Arts, 2010 \\ Immigration and Settlement Studies \\ Ryerson University
}

\begin{abstract}
$\underline{\text { Abstract }}$
Media and public discourses are constantly changing as a result of their effect on one another. The Consultation Commission on Accommodation Practices Related to Cultural Differences which roamed the province of Québec in late 2007 was widely reported on in the mainstream news-media. This paper provides a critical content analysis of 105 articles in three Québec daily newspapers (La Presse, Le Soleil, and The Gazette) during the months of September to December 2007 when the public forums discussing the reasonable accommodation of minority groups took place. By making theoretical linkages with the data collected, the findings show that the media discourses between the three newspapers vary slightly and are not accurate representations of the public discourses surrounding the issue of reasonable accommodations amongst the Québec population.
\end{abstract}

\section{$\underline{\text { Résumé }}$}

Les médias et les discours publics changent constamment en raison de leur effet un sur l'autre. La Commission de consultation sur les pratiques d'accommodement reliées aux differences culturelles qui a fait le tour de la province du Québec vers la fin de 2007 ont été largement rapportées dessus dans les journaux traditionels. Cet article fournit une analyse critique du contenu de 105 articles de trois quotidiens au Québec (La Presse, Le Soleil, et The Gazette) du mois de septembre à décembre 2007 où les forum publics discutant l'accommodement raisonnable des groupes minoritaires ont eu lieu. En faisant des liens théoriques avec les données de l'analyse, le résultat est que les discours des médias entre les trois journaux varient légèrement et ne sont pas les représentations précises des discours publics entourant la question des accommodements raisonnables parmi la population du Québec.

Keywords: Reasonable accommodations - Québec immigration - Media discourse - Public discourse $\cdot$ Québec nation

Mots clés: Accommodement raisonnables - Immigration Québec - Discours médiatique · Discours publique $\cdot$ La nation québécoise 


\section{Acknowledgements}

It would be inappropriate to take full credit for this MRP and my Masters degree. In my personal life, my parents in particular have supported me throughout my academic and professional career; without your unconditional love and support I would never have achieved as much as I have. Thank you to my partner, Éric, who gave me the final push to make sure I saw this task to the end, and has travelled countless kilometres to help me do so; you are a wonderful man. I would also like to thank the rest of my family, my close friends, and my roommates who have helped me out over the years, and came to visit me or called me while I was studying 'abroad'. I'm not sure 1 would have had the confidence to take on this journey without all of your kind words. I love you all and thank you.

To my Immigration and Settlement Studies professors and colleagues, thank you for the challenges and the wonderful memories I will take away with me. I look forward to reading all of your future work and hopefully working with some of you again in the future. Thank you to Marco Fiola, my supervisor, for keeping me on track, and for the laughs in your office when I was feeling the walls closing in on me. Also, with the most sincere respect, thank you to Doreen Fumia for challenging me academically and helping me through to the end. Last but not least, thank you to my close friend and colleague Anya Hussain, who helped me stay sane and occasionally lost her mind with me; I am happy to call you a friend. Thanks for the great times! 
Table of Contents

1 Introduction $\quad$ p. 1

2 Background $\quad$ p. 3

2.1 Reasonable Accommodations: History p. 3

2.2 Demographics of Québec's Immigration p. 7

3 Literature Review $\quad$ p. 11

4 Methodology p. 18

5 Results $\quad$ p. 22

5.1 Qualitative Analysis $\quad$ p. 22

$\begin{array}{ll}5.2 \text { Quantitative Analysis } & \text { p. } 28\end{array}$

5.2.1 Religion and Secularism p. 29

5.2.2 Socio-Economic and Cultural Integration p. 33

5.2.3 Tolerance, Diversity and Other p. 35

6 Discussion $\quad$ p. 38

6.1 La nation québécoise (The Québec Nation) p. 40

6.2 Religion $\quad$ p. 41

$\begin{array}{ll}6.3 \text { Language } & \text { p. } 43\end{array}$

$\begin{array}{ll}7 \text { Conclusion } & \text { p. } 45\end{array}$

8 Appendix p. 51

$\begin{array}{ll}9 \text { References } & \text { p. } 58\end{array}$ 


\section{Introduction}

The focus of this paper is to show how the public debate regarding the reasonable accommodations of immigrants ${ }^{1}$ and cultural minorities in Québec has been reported and influenced by different media discourses surrounding the Consultation Commission on Accommodation Practices Related to Cultural Differences. The emphasis will remain on print news-media, as this form of news-media is regarded both as a credible source of information and as an accurate representation about the world $(\mathrm{Li}, 2001)$. I have chosen to study print form rather than other forms of media such as television or radio news due to the time and resource constraints of this research study. By studying news-print media the analysis in focused on language, and ignores other factors such as body language, tone of voice, or visual setting (Fairclough, 1995). This kind of analysis would require greater resources in order to study accurately.

Québec is a heterogeneous society where French is the official and as well as the language of the majority, yet it is surrounded by English-speaking societies with their own media discourses. Like the makeup of the province, there are differing opinions on the subject of reasonable accommodations as well as different definitions of the 'Québec nation', and hence there are competing discourses both in the media and the public on how to integrate newcomers into a society still in the process of defining itself (Bouchard, 1999).

To guide me in my research several questions need to be addressed: What is the extent of difference in the media discourse between different media outlets? This question lies at the center of this research, in that the ultimate aim is to know if there are any differences between mainstream news-print media outlets. The answer to this question will allow me to answer the

\footnotetext{
${ }^{1}$ The terms 'immigrant' and 'newcomer' will be used interchangeably throughout this work. Both terms refer to persons who have migrated from a country other than Canada to Québec, and does not include second-generation immigrants, who would be those born in Canada to immigrant or newcomer parents.
} 
following questions: How do competing media discourses affect the overall public discourse? How may public discourse shape the media discourse in turn? Is there a disconnect between media and public discourse? These questions shall be answered by marrying the theory to the findings of the empirical research.

The relationship between media discourse and public discourse is often explained in a causal manner, with one influencing the other. At other times, the relationship is viewed as symbiotic, where each discourse shapes and affects the other. News media outlets report on occurrences, and while their stated goal is to attempt to be objective and factual, Fairclough (1995) would argue that they inherently portray a one-sided image for a variety of reasons such as who own, controls, and creates the news media. These stories ignore the voice of the 'other', which for the purpose of this paper the focus is on the immigrant 'other'. As the result of Western, male-dominated mainstream media discourse, public discourse regarding immigration is changed, in part through the misinformation provided by this powerful participant. Yet, in the case where news media reports on events such as public consultations, it can be argued that the public discourse first shapes the media discourse ${ }^{2}$, which then in turn reshapes public discourse based on how media has chosen to report, or not report, the public discourse. The relationship is rarely so clear though, as other actors such as politicians, celebrities, and institutions may interject with their own opinions which alter perhaps both the public and media discourses.

\footnotetext{
${ }^{2}$ According to Foucault (1978), discourse is a series of symbols and statements which hold meaning and have power. In the context of this research study, the term discourse refers to the language used in the public and the media, and that language which is excluded in order to express a view held by those with the power to express such opinions.
} 


\section{Background}

\subsection{Reasonable Accommodations: History}

Under Québec's Charter of Human Rights and Freedoms, the State, individuals or corporations are sometimes required to adjust the legitimate standards, practices or policies they apply to all people, without distinction, to take into account the particular needs of specific categories of people covered by a ground of discrimination. In Québec and Canadian law, this duty of 'reasonable accommodation' ('reasonable' in the sense that it can be provided without 'undue hardship') is considered to be a 'natural corollary' of the right to equality (Bosset, 2005: 1).

The demographic make-up of newcomers to Québec has remained relatively similar since the signing of the Canada-Québec Accord in 1990 which granted the province full control over the selection of immigrants destined for its territory. It is approximately at the same time that cases of requests for or denial of reasonable accommodations began to surface in Québec's media discourse. There are several examples of such requests that have taken place in the last couple of decades which may provide a clearer understanding of the history of the reasonable accommodation debate in the province. In 1994 a Québec-born girl and recent convert to the Islamic religion named Emilie Ouimet was expelled from a French-language public high school for refusing to remove her hijab, a head covering worn by Muslim women, in the classroom. Several years later, in 2002, another debate began in the school system and attracted nation-wide attention and was later brought before the Supreme Court of Canada. This was the case of a LaSalle boy who was suspended from attending school for several months as a result of wearing a kirpan. A kirpan is a ceremonial dagger and religious symbol, much like the Catholic cross or Jewish kippa, carried by Sikh men and boys, not a potential weapon as the boy's school at the time was claiming (Hamilton, 2002; Thompson, 2006).

Outside of the school system, the Hasidim, a branch of the Orthodox Judaic faith, have been a target of arguments against reasonable accommodation. In the Mile-End neighbourhood 
of Montréal is one of the largest Hasidim populations in the province. In 2006, a Hasidim synagogue approached their YMCA neighbours in order to negotiate a way in which to accommodate both synagogue-goers and gym patrons. The Hasidim's complaint was that women who exercised in tight and revealing clothing were viewable by boys attending religious classes at the synagogue, and that seeing women in such attire is against their religion. A solution based on reasonable accommodation was agreed on between both parties that the synagogue would pay to have the YMCA's windows frosted. The YMCA patrons contested this course of action with a petition, claiming it was up to those who may be offended by the women's attire to frost their windows or take another course of action which did not directly affect the female patrons who felt that they should not be penalized as a result of the unease of others (Ouimet, 2006). A month earlier, Montréal police were instructed to have male officers deal with Hasidic men. This followed the case of a Hasidim refusing to acknowledge the authority of a female police officer when attempting to intervene following a traffic violation (Sutherland, 2006).

These events are at the heart of Québec's internal debate on how different members of society should interact with one another, and how the Québec nation and its institutions should accommodate minority groups and individuals without losing their distinct Québécois identity while allowing for the religious freedom and cultural expression of all. The notion of the Québec nation and interest in preserving this collective identity as well as the respect for individual rights and freedoms shall be discussed in greater detail in later in this section.

Following this series of stories of reasonable accommodation covered by the media, the small rural town of Hérouxville in central Québec passed a series of municipal Standards to take effect in 2007, which required potential immigrants were to abide by. While the authors of these 
Standards deny that their aim was at all racist or discriminatory, the contents of the Standards contained elements that demonstrated the stereotypical, racist and discriminatory beliefs they held, particularly in relation to Muslims. Some of the elements contained in this document highlighting these beliefs include the promotion of equality of the sexes, democratic values, and of integration into the host society. The assumption that Muslims and newcomers of other faiths and cultures hold views which are contradictory to those views held by the majority of Québécois is baseless, in that it was their own biases which informed the content of the Standards rather than research or other forms of reliable information. While such elements may seem to uphold a liberal notion of justice, the document demonized the immigrant 'other' as well as highlighted many of the fears held in rural Québec in particular.

Nieguth and Lacassagne (2009) document that following the adoption of the Hérouxville Standards, which was widely discussed both within and outside Québec media sources that the provincial government decided to intervene and form the Consultation Commission on Accommodation Practices Related to Cultural Differences (hereafter referred to as the BouchardTaylor Commission ${ }^{3}$ ). The Bouchard-Taylor Commission was given the following mandate:

Take stock of accommodation practices in Québec; analyse the attendant issues bearing in mind the experience of other societies; conduct an extensive consultation on this topic; and formulate recommendations to the government to ensure that accommodation practices conform to the values of Québec society as a pluralistic, democratic, egalitarian society (Québec, 2008).

The two men selected to head this commission were Gerard Bouchard and Charles Taylor. At the time of appointment, Dr. Bouchard was a sociologist and historian, and a professor at the Université de Québec à Chicoutimi. He is also the brother of former Parti Québécois leader and Québec premier, Lucien Bouchard. He grew up in a French-speaking

\footnotetext{
${ }^{3}$ The name 'The Consultation Commission on Accommodation Practices Related to Cultural Differences' was often shortened to 'The Bouchard-Taylor Commission' in the media, in reference to the two chairs of the Commission.
} 
home in Jonquière, a mid-sized city in the Saguenay region. Dr. Taylor is an author and philosopher, and is a professor at McGill University in Montréal. He was raised in a bilingual home in Montréal. As is typical in Québec, in order to maintain the appearance of objectivity, Dr. Bouchard is a Québec nationalist and Dr. Taylor is a Canadian federalist. Given the controversial ethnic and religious nature of the commission in question, and in order to attempt providing it with greater legitimacy, the two commissioners were selected on two different sides of the religious debate as well: Dr. Bouchard is a secularist whereas Dr. Taylor is open about his traditional Catholic beliefs (Québec, 2008). While the provincial government attempted to represent the two largest groups in Québec, both in terms of language and religious identification, it left those cultural and religious minorities who were being discussed without any representation within the framework of the Commission or its commissioners.

The selection of these two men as commissioners for this debate has been criticized as non-representative of those communities which were being targeted for the discussion. There is precedence for this criticism since the Québec government has traditionally had other forms of representation such as political, sex or gender. Given the mandate of the Bouchard-Taylor Commission, various community groups have argued in front of the Commission that at least one of the following groups should have been represented in the body of one of the commissioners: women, immigrants, religious minorities, 'racial' minorities, persons with a physical handicap, or the LGBT community.

There were several formats which were adopted in order to obtain information from the public on the subject. Individuals, groups, or organizations could submit deputations regarding their stance or stake in the issue, or could simply voice their opinion in a "regional citizens" forum" at any of the eighteen consultations that took place throughout the province. The 
Commission received 335 deputations and held twenty public meetings (Québec, 2008). The final report was complete in early 2008 ; however, to date the government has not implemented any of its recommendations. To elaborate, some of the report's recommendations included greater intercultural training in the workplace and classroom; the legislation of an official gender equality clause in the Québec Charter; and various means of greater immigrant integration both through improved language training and recognition of skills and education (Bouchard and Taylor, 2008).

\subsection{Demographics of Québec's Immigration}

The province of Québec, with the metropolitan area of Montréal in particular, has always been one of the largest immigrant receiving centres in Canada. This urban area receives over 80 per cent of all immigrants to Québec and 12 per cent of all immigrants to Canada (CIC, 2005b). Over the last 30 years it has become the primary destination for those immigrants coming from countries such as Haiti, France, and several North African nations, where French is one of the official languages (Québec, March 2009). Prior to this period, when Québec had virtually no control over immigration policy and had not yet enacted language laws intended at protecting the status of the French language such as the Charte de la langue française, most immigrants integrated into the minority Anglophone community for a variety of reasons, including economic and social inclusion. However, with the province gaining control over selection of immigrants destined to settle within the province, as well as enacting laws streamlining immigrants into the Francophone school system, more recent cohorts of newcomers are increasingly integrating into the majority Francophone community (Québec, 1990). Therefore, the debate over how to assist immigrants in the process of integration is a rather new one for the Francophone community, one 
that had previously established Québécois culture and collective identity. It is within this context that the debate over reasonable accommodations of ethnic, religious, and linguistic minorities commenced.

The province of Quebec receives over 45,000 newcomers each year who speak over 150 languages, with origins in over 180 countries (Fall and Vignaux, 2008). 86.9 per cent of immigrants settle in Montréal, an urban centre that represents only 45 per cent of the provincial population. This percentage has remained relatively unchanged for several decades (Québec, 2009). For the period of 2004-2008, the economic immigrant class represented 61.3 per cent, with 3.6 per cent coming as entrepreneurs or investors; 22.1 per cent belonged to the family reunification class; 14.4 per cent came to Québec as refugees; and the remaining 2.2 per cent fell under the "other" category (Québec, March 2009). In comparison to the rest of the country, this represents the largest admission rate for the skilled worker class and the smallest family reunification category proportion (Grondin, 2007).

Another major difference between Québec immigration and immigration flows in the rest of Canada is the list of source countries or regions of these newcomers. In Canada, two out of three newcomers are from Asia, whereas this figure in Québec in 2008 represented less than one in three. The majority ( 30.4 per cent) of newcomers to Québec, since 2006, originate from Africa, over half of which come from North Africa. The Americas come in a close third for continent of origin, with most immigrants from this region coming from Haiti or South America (Québec, March 2009). Algeria, France, and Morocco have been the most important source countries for Québec immigrants, representing 23.6 per cent of the total number of immigrants to the province (Québec, 2009). In complete contrast Canada's top three source countries for immigrants (China, including Hong Kong; India, and the Philippines) represent 33 per cent of the 
total influx (CIC, 2005a). Of the top ten source countries for both Québec and Canada, only two overlap: China and the Philippines, but with significant differences in their comparative importance.

Most newcomers to the province are under the age of 35 years (69.9 per cent) (Québec, 2009), and more than 30 per cent have a university degree. In comparison to immigrants who settle elsewhere in Canada as well as the Canadian-born population, immigrants to Québec are the youngest and most educated. Also, the proportion of immigrants with non-university, postsecondary training is also higher than the Canadian-born (CIC, 2005b). Thus immigrants to Québec are generally younger and more highly educated and skilled than those who immigrate to any other province.

Concerning French language skills, over 60 per cent of newcomers declared, based on self-declared French-language ability, that they had an understanding of the language, with this number rising to over 75 per cent for those who landed as skilled workers (Québec, 2009). However, of those immigrants arriving in 2008, only 15 per cent of newcomers spoke French as their mother tongue and 23.4 per cent spoke only French at home prior to migrating (Québec, March 2009). Immigrants to Québec are somewhat less likely to have French-language skills upon arrival than immigrants to other provinces will have English-language skills, but this differential represents less than 5 percent. However, the language skill levels of immigrants to Québec do compare to immigrants elsewhere in Canada within a few years of settlement primarily as a result of language training.

The factor where we see the most difference is that it is more likely that in Quebec for immigrants to have English skills but no French skills, which is the official language in the province. This is different from the rest of the country where immigrants similarly have a 
greater likelihood of having English rather than French skills, but this is not viewed as problematic as English is the language most often used by native-born Canadians in other provinces. In Quebec, 40 per cent of non-English speaking immigrants can speak English within six months of arrival while only 10 per cent of non French-speaking newcomers are able to speak French in all other provinces. It is also significantly more frequent for immigrants to Québec to be bilingual in both official languages than elsewhere in the country, with 36 per cent claiming knowledge of both official languages in Québec versus fewer than 10 per cent in the rest of Canada (Grondin, 2007).

Often such numbers and statistics regarding immigrants are used by the media, political parties and other stakeholders to argue that such numbers of non-French speaking immigrants are a threat to the status of the language in Québec. Similarly, such figures regarding source countries illustrate an increased importance of non-Christian religions in population demographic, and are also used to portray such newcomers as a danger to the culture of the province. It is disappointing, because such figures as those shown in the language discussion above, show that most newcomers to the province are more often successful in integrating linguistically upon arrival than elsewhere in the country as well as are more often bilingual. Rather than focus on such positive information as well as selected immigration figures, often political actors and the media that reports on their platforms give on-sided information (Mahtani, 2001). Therefore, the media is one player that has contributed to portrayal of an image of newcomers that led to the debate over reasonable accommodations and how much the nativeborn population should be willing to accommodate newcomers. 


\section{Literature Review}

Prior to undertaking this topic, I assumed that the representations of immigrants and visible minorities in the media would have been a widely studied topic, both in Québec as well as elsewhere in the world. It has been surprising to see how little discussion there has been in the academic literature concerning to media portrayals of immigrants to Québec in general, especially how much this subject is covered by the media. In this literature review, I will offer the various debates about what has been said about media portrayals of immigrants in Québec and elsewhere, how the debate began, and how the debate in Québec French media differs from discourses in other media outlets.

The debate over reasonable accommodations is one that has always existed within the Canadian context. In The Making of the Mosaic (2000), this debate predates immigration as we know it today, back to the negotiations of how to accommodate the French Fact of Lower Canada into the Canadian Confederation during the $18^{\text {th }}$ century. Although policymakers of the time would not have used the term 'reasonable accommodation', they were discussing how many protections should be awarded to the French Canadian population based on their unique language, religion (i.e. Catholicism), and legal code (i.e. civil law). The earliest official policy which attempted to appease the needs of French Canadians was the Québec Act of 1774, and other protections have been allotted over the years in other policies, up until the modern day.

In various other works, the reasonable accommodations debate is said to have begun with the 1985 Canadian Supreme Court case of the Ontario Human Rights Commission v. SimpsonsSears (Nieguth \& Lacassagne, 2009; McAndrew, 2010). These authors use this case as their starting point because it was the first instance where a legal intervention was required in settling the conflict between two groups regarding the accommodation of one's religious practices. Prior 
to this case the legal institutionalization of the protection of religious rights, as enshrined in the Canadian Charter of Rights and Freedoms, was non-existent and such a legal challenge would not have had any grounds upon which to build an argument.

In Québec there were a series of events including both legal challenges and news stories which led to the creation of the Bouchard-Taylor Commission on Reasonable Accommodations. As mentioned earlier, the cases of Emilie Ouimet and the adoption of the Hérouxville Standards were two such incidents that were discussed widely in Québec media discourse. There were also some individual cases of requests for accommodation, mostly requests relating to a request for religious accommodation, which were severely scrutinized in the media. While some authors acknowledge that these were not the first of such debates to exist in the province, the discourse surrounding these cases and the Commission in particular was very different from earlier public discourses on how to accommodate minorities, including immigrants (Nieguth \& Lacassagne, 2009).

The media plays a significant role in communicating discourses of identity, of both the self and the 'other' (Todd, 1998; Mahtani, 2001; Jiwani, 2005). This is important to remember, because while both producers and consumers of media are encouraged to believe that the purpose of media is to convey an objective and value-free representation of the world, media is inherently political and biased (Li, 2001; Mahtani, 2001). Below I discuss how this is demonstrated in a variety of media sources.

$\mathrm{Li}$ (2001) argues that in a multicultural democracy such as Canada, racist discourses in the media are not overt in nature. Rather, Canadian media uses methods of "new racism", by which he means that the discourse will use coded terms (p. 78). Therefore, when discussing issues related to immigration the media will take for granted that Canadian mainstream culture is 
a white, European, Judeo-Christian one, and as a consequence questions of diversity, or 'otherness', need to be negotiated since they are viewed in opposition to this norm and thus it is the requirement of the diverse 'other' which must be integrated into the mainstream. This is because it is assumed that immigrants from non-traditional sources ('them') have values and beliefs that are so much different from the Canadian ones ('us'). Having taken a critical discourse approach, the author warns that even when language appears more socially acceptable, the reader must always understand the hidden messages in the terms chosen as well as the context within which these discourses arise.

$\mathrm{Li}$ also claims that the media use a variety of such techniques to 'other' immigrants and visible minorities in covert ways that would not be considered obviously racist. He states,

In this article, I examine the articulation of race in Canada's immigration discourse and argue that racial messages are often articulated subtly in a democratic society such that their nature, form, and effect are elusive. The use of racial subtext, that is, the hiding of racial signification in a benign discourse and conveying it in coded language, represents a sophisticated way of articulating 'race' in a democratic society that makes such articulation socially acceptable. ( $\mathrm{Li}, 2001: 77-78$ )

Opinion polls, conducted by private companies such Leger Marketing and Ipsos, are one such method incorporated by producers of media. These polls, based on the subjective responses given from an often uninformed populace, are then used to misinform the population on a topic with data that $\mathrm{Li}$ claims is not objective in nature. There is an argument to be made here that knowledge can never be objective. However, the knowledge being produced through such methods as opinion polls is not based in research or theoretical understanding, but is generalized. It is a vicious cycle, whereby the media take subjective information and pass it off onto an unsuspecting public as objective truth, often further perpetuating the myth of the diverse and different "other' in comparison to the normative "us". In addition, such opinion polls support the 
use of racial categories in discourses about immigration. Finally, by using softer terms such as visible minorities as opposed to members of 'racial' categories, consumers of media are less likely to question the motives of the producer of the media.

Mahtani (2001) states that 'traditional' forms of media do not allow for different or dissenting voices to be heard, rather than claiming that there is a hidden racist agenda. However, while the intent of producers of media is not necessarily to promote racist ideals, they do institutionalize racism through their ignorance and reinforcement of dominant discourses. There are two major problems she highlights in her article Representing Minorities: Canadian Media and Minority Identities: under-representation and misrepresentation of minorities in media. While her analysis is of visual media in particular, it could be transferred and applied to print media as well. In the case of the coverage of the Bouchard-Taylor Commission on Reasonable Accommodations, it is the latter misrepresentation which can be argued has been the greater problem. In this media discourse, immigrants as well as cultural and ethnic minorities were the topic $d u$ jour, where the discourse portrayed the levels of integration on the part of these populations as insufficient and therefore problematic.

It is common to hear people outside of academic circles say that the discourses about immigration as a phenomenon and immigrants more specifically have changed since the attacks of September $11^{\text {th }}, 2001$. Jiwani (2005) would seem to agree, in that the language used has changed in regards to 'us versus them'. Her emphasis was to focus on the language used about Muslims and Arabs in particular, and so her analysis does not apply to all immigrants to Canada. It does reflect though how racism can become more overt even in a nation as 'tolerant', 'diverse', or 'open' as Canada. She found that the language used in much of the media immediately following the September $11^{\text {th }}$ attacks emphasized the tolerance, democracy, and humanitarianism 
of Canadians, while those who 'look like Muslims' (including Sikhs and Hindus, for example) did not exemplify such values. Therefore, the author's conclusion is that those values which Canadians hold dear are 'white' values, and even if the media did not make this point directly, the discourse which they created was that 'non-whites' will never be like 'us'. According to the literature explored above, the media can exert both covert and overt racist discourses.

Certainly, some of the claims made in the previous paragraphs apply in the context of Québec media as well, although there are some differences. Thomas (1992) claims that while some of the differences in English and French-Canadian media are because of certain cultural and linguistic elements, the main reason for such difference can be explained through the institutionalized policy of media in Canada and Québec. The Canadian Radio-television Telecommunications Commission (CRTC) is the governing body of media for all regions including Québec, although its regulations regarding the English and French sectors vary primarily in terms of content. These regulations, as well as dominant cultural interests, promote a greater emphasis on local news in Québec in comparison to the rest of the country. Therefore, while English Canada receives most of its information from American and English Canadian media conglomerates, Québec has its own media, therefore including a third source of information in the media mix. However, because the CRTC grants licensing to 'ethnic' media rather than regulating the inclusion of these voices in mainstream media, the opinions of newcomers are not readily available to either French or English Canadians through more mainstream channels.

Todd (1998) and Helly (2004) have each done research, using content analysis and comparing French and English media, showing the differences in how French Québécois and English Canadians obtain different information regarding the same debates. Through a 
psychoanalytic lens, Todd investigates how English and French media discussed the right of wearing the hijab and other religious symbols in public schools in Québec. In her analysis she discovered that the English daily in Montreal, The Gazette, listed Emily Ouimet's battle of the right to wear the hijab an issue of rights, briefly mentioned above. For a little background, Emily Ouimet was a 12-year-old convert to Islam who was forbidden to wear the hijab at her public high school, as all such symbols were not permitted. The French newspapers, Le Devoir and La Presse, however were involved in a debate about confessional schools versus secular schools. Their claim was that in Québec's recent history of secularizing all state institutions, including public schools, that the right to any religious symbols should be banned outright. It is noteworthy that at the time Québec was in the process of cutting education budgets and eliminating confessional school boards in lieu of secular, linguistic ones. Todd (1998) explains the difference in the following way. Debate in the French print media was a reflection of the greater debate which existed in Québec at the time, where French-Québécois were gaining greater control over their own nation-building project, and moving away from a history of domination and oppression. On the other hand, English newspapers were easy to jump to criticize anything said in the name of Québec nationalism, and this debate fell under that discursive umbrella.

In contrast to the above argument, Helly (2004) views French-Québec media as being "less offensive and ambiguous" towards minorities, in this case Muslims, than English media in the rest of Canada (p. 19). The author interpreted that French news media often tended to include reasons for which the terrorist attacks of September $11^{\text {th }}$ happened, while English news media simply painted the terrorists as 'Islamic fundamentalists' who hate Western values. In regards to immigration policy, the Francophone news media were also less likely to make calls 
for revision to current policies in order to protect 'us' from 'them'. This suggests that French media discourse tends to be more focused on the social context and understandings of an occurrence, and is inherently more open to critiquing the reasons for recent events in comparison to English language media in Canada.

Such debates can affect the social integration of immigrants to Canada in several ways, both in forms of pressures or barriers placed on newcomers as well as self-limiting actions. Esses et al. (2001) explain how certain models or orientations of interaction between 'mainstream' society and 'out-groups', in this case immigrants, affect their ability to integrate. Immigrants may not be permitted to participate fully in their new society because members of the host society view 'them' as a threat or competition for scarce resources, as the authors explain through their Instrumental Model of Group Conflict. Media fuels such fears, especially among people whom the authors refer to as being of a Social Dominance Orientation, who believe in a natural hierarchy within the social order, where one group of individuals is superior to others for reasons that can include at best ability and intelligence, or at worst socially constructed differences such as 'race' and 'gender' for example. Once believed by enough people in the host society, these perceptions can affect policy or other factors which prevent the immigrant from full social integration.

Greer and Jewkes (2005) as well as Wortley (2009) on the other hand would argue that it is through exclusion of newcomers into the 'mainstream' society that certain newcomers come to exhibit criminal or deviant behaviours. If newcomers are not permitted to fully participate in society, or even worse, face multiple discrimination barriers to accessing employment and so on, that they feel it necessary to commit crime in order to survive. This scenario is more common among underprivileged immigrant youth, who have very few outlets or resources to improve 
their social standing. Media contributes to the demonization of immigrants, portraying 'them' as criminal, which further portrays the stereotype of newcomers as a threat. By further institutionalizing such stereotypes, media allows for justification to treat newcomers as such. When media demonizes immigrants, it in essence it creates a self-fulfilling prophecy.

The focus of this literature review has focused on the portrayal of immigrants and visible minorities, and therefore has emphasized the cultural debates surrounding the increased diversity in Canada as a result of immigration. While this has been the aim of this paper, Bauder (2008) would argue that this is not a fully accurate portrait of the debates surrounding immigration in this country. Based on his content analysis of English newspapers from across Canada, excluding Québec, he has found that the most important debates regarding immigration stems from both positive and negative opinions on the economic ramifications of existing policies and practices, humanitarian concerns, and worries about issues of national security. It remains to be seen if these debates are of similar importance in Québec or, because of the nature of Québec nationalism, if reasonable accommodations based on cultural practices are of greatet concern in the discourse on immigration policy.

\section{Methodology}

To investigate how discourse differs between newspapers in the province in terms of the portrayal of immigrants as discussed in the reasonable accommodations debate, I will employ a content analysis of three newspapers: The Gazette, Le Soleil, and La Presse. The timeframe which will be analysed will cover the period of September $10^{\text {th }}$ to December $14^{\text {th }}, 2007$, when the Bouchard-Taylor public consultations were taking place as well as one additional day of news following the final day of consultation to allow for any publishing delay. By juxtaposing the 
discourses of English and French newspapers as well as between Montréal and regional newspapers, we may see how the reasonable accommodations debate in Québec was portrayed differently within some of the different communities in the province. This method also allows for a broader understanding of what discourses existed in the province at the time, and provide some background to how such opposing discourses came about. Therefore, I have chosen to look at daily newspapers as they will have a more extensive coverage of the reasonable accommodations debate. For this reason, I draw on an English-language daily newspaper in Montréal, The Gazette (the only mainstream English daily in the province), the French-language daily newspaper La Presse (for an urban Francophone perspective) and, Québec City's largest daily, Le Soleil (for a regional perspective). In selecting my media sources, the hardest decision was settling on a French-language daily newspaper from Montréal. There are three mainstream daily French-language newspapers in Montréal: La Presse, Le Journal de Montréal, and Le Devoir. I dismissed rather quickly the possibility of including Le Journal de Montréal as it is commonly viewed as a 'tabloid' style of newspaper. This left me with the 'other two to select from, however, La Presse has a larger circulation than Le Devoir among the population and hence its selection for my analysis. Overall, it has been found that La Presse is viewed as the preferred newspaper among people with higher levels of education and income, and hence compares more greatly to the readership of both The Gazette and Le Soleil does than either of the other French-language dailies I could have selected for this content analysis (Dunn, 1998).

I have purposely chosen to exclude any newspapers that are viewed as 'ethnic' or 'alternative'. There are several reasons for this. First, there are no such newspapers in the province which are printed on a daily basis. Second, the readership of such newspapers is significantly less than the daily newspapers I have chosen to analyse. Finally, while all media 
generally have a target audience, 'ethnic' and 'alternative' media have a very specific target audience which means that much of the Québec population has little or no access to them. Given that my goal is to study the mainstream media discourses, diverse media sources would be inappropriate for this research study, and would only lead to greater difficulty in understanding and critiquing the mainstream discourses.

A content analysis, while not required to be of a mixed methods nature, often employs both quantitative and qualitative methods for data collection. I will begin quantitatively by taking count of how often keywords appear in all articles for the time period in the three selected newspapers. The initial list of keywords that I have chosen is simply reasonable accommodations and Québec, as well as its French equivalent accommodements raisonnables and Québec. In order to search these keywords, I used two separate search indexes: Eureka in order to search within the two French-language papers, and Canadian Newsstand through Proquest to search The Gazette. The first point of analysis will be to determine the frequency at which these keywords appear and comparing this frequency between the three newspapers. It would be insufficient to employ solely such an analysis as it would not give a very descriptive account of how these issues are being discussed within the articles. Therefore, a second level of analysis is necessary.

A qualitative analysis in the form of a critical discourse analysis of the contents of each article will follow and will allow for a greater understanding of themes found within the news articles containing the matching keywords (Fairclough, 1995; Chouliaraki and Fairclough, 1999). One of the main concerns for anyone employing a qualitative content analysis is the reliability of their results. This method is hard to replicate as the interpretation of the data, and even elements of the selection, are of a subjective nature in determining what themes and coding schemes 
should be included. In order to ensure that my analysis is more reliable, I will summarize the selected articles using inductive category formation (Mayring, 2000). For example, given that I must first answer the question "What is the media discourse regarding reasonable accommodations in Québec?" my first categories will be divided among the different discourses. Some themes that I suspect may arise would refer to social, economic, political and cultural integration, and that these articles would argue either favourably for reasonable accommodations of immigrants who require special accommodation, and articles which argued against such accommodations for newcomers. Once these initial categories have been determined, then a second level of analysis is done for each theme to divide them into more specific sub-themes. In this way, the interpretation of the data can be more specific and reliable, in that the steps could more easily be replicated by others which would lead to similar findings.

In order to qualitatively analyse the media discourse within the selected newspapers, I will employ a critical discourse analysis approach. Fairclough (1995), the developer of this theoretical approach, argues that there is a symbiotic relationship between media and the society within which it is generated. Therefore when studying media discourse researchers must perform an "intertextual analysis" whereby the discourse must be looked at with an understanding of the social. and cultural context from where it arises (p. 61). This is required regardless of the text being studied, which the author specifies can be anything found in media: images, written text, audio-visual, or any other vehicle through which the media discourse is being communicated (p. 58). Not only should media discourse be analysed with an understanding of the context in which it is generated, but also it should be compared. To analyse simply one discourse allows for description, yet it lacks in-depth understanding without comparison to other discourse, either within media or social discourses. 
Thus, the articles analysed in this literature review have been chosen because of their critical reading of existing media discourse. Some of the articles reviewed are not of a critical theoretical approach; however, they do contribute to a direct analysis of media discourse in regards to the creation of the 'other', and are therefore useful in this paper. Where possible, I have noted the lack of critical analysis in these works.

\section{Findings}

\subsection{Quantitative Analysis}

Figure 1 - Articles Found with Selected Keywords

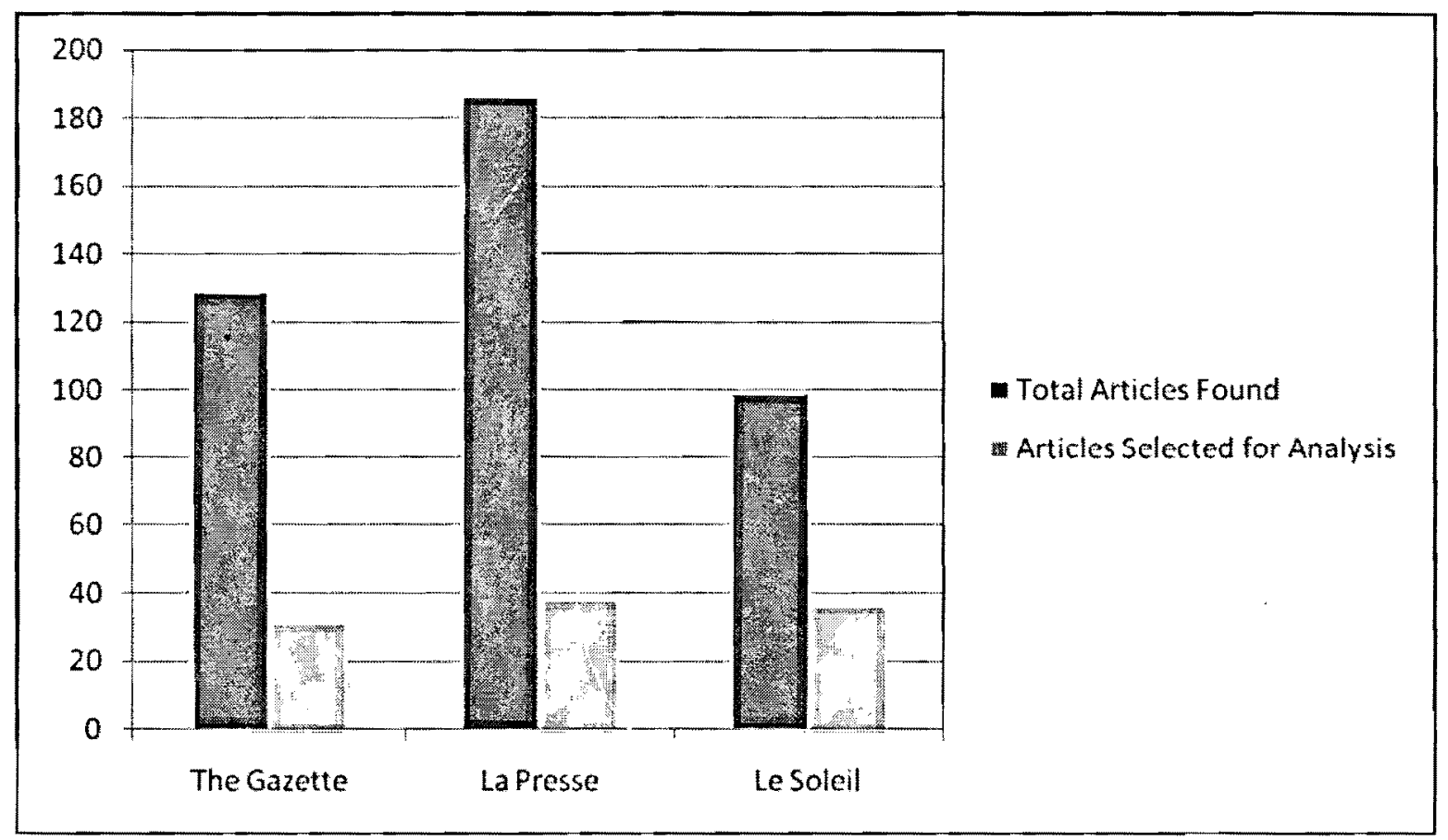

The first step of inputting my selected keywords, reasonable accommodations and Québec, as well as the French equivalents, accommodements raisonnables and Québec in the two search indexes, Eureka and Canadian Newsstand, yielded a total of 414 articles in the three 
Thus, the articles analysed in this literature review have been chosen because of their critical reading of existing media discourse. Some of the articles reviewed are not of a critical theoretical approach; however, they do contribute to a direct analysis of media discourse in regards to the creation of the 'other', and are therefore useful in this paper. Where possible, I have noted the lack of critical analysis in these works.

\section{Findings}

\subsection{Quantitative Analysis}

Figure 1 - Articles Found with Selected Keywords

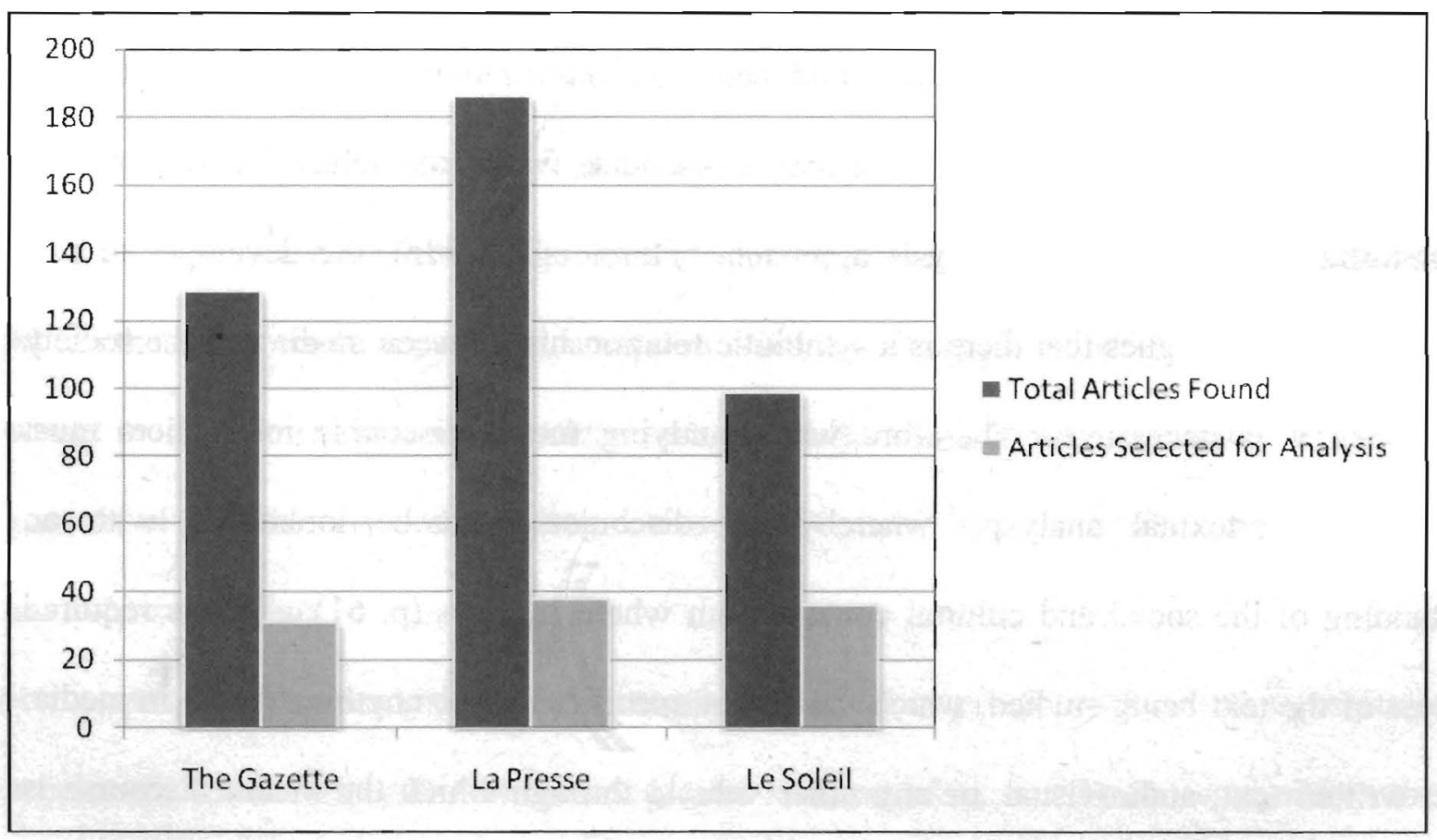

The first step of inputting my selected keywords, reasonable accommodations and Québec, as well as the French equivalents, accommodements raisonnables and Québec in the two search indexes, Eureka and Canadian Newsstand, yielded a total of 414 articles in the three 
newspapers for the selected dates. As can be seen from the above table (Figure 1) the number of articles in each newspaper varied slightly: La Presse published the most with 186 articles, The Gazette published 129 related articles, and Le Soleil provided the least number of articles containing the selected keywords with 99 articles. Given the similarity in the size of the three newspapers, the difference in the number of articles containing the keywords chosen could lead to the impression that La Presse was more interested in covering the Bouchard-Taylor Commission that was touring the province. However, after individually looking at each news article in order to determine those that pertained to the coverage of the Commission itself, the numbers between the three papers becomes much more comparable: La Presse published 38 articles, Le Soleil printed 36 relevant articles, and The Gazette published 31 articles covering the discussions held within the framework of the Bouchard-Taylor Commission. Syndicated news articles were also eliminated for the reason that I wanted to know how these newspapers covered the Commission, and syndicated articles are written by journalists from other newspapers. Therefore the total number of articles kept for further analysis was 105 articles.

When looking at the findings from the quantitative analysis it may be noted that while $L a$ Presse perhaps was interested in the issue of reasonable accommodations in comparison to the other newspapers, all three newspapers showed similar interest in providing coverage of the Commission itself. The original number of articles discussing reasonable accommodations overall was higher in the former newspaper, but when controlling for only original articles covering the debate in the confines of the Bouchard-Taylor Commission, there was little variability between the newspapers. Given that the purpose of this paper is to analyze the newsprint media's coverage of a particular event, it can perhaps be explained that the coverage 
correlates with the dates where a public consultation was held or when a large organization presented a written brief to the commissioners.

With the articles for further analysis determined, a coding scheme was necessary in order to determine what some of the common themes may be. Because there was very little literature regarding the idea of reasonable accommodation and therefore a lack of a model which to follow or themes known to have arose in the past, it was decided that it would be wise to begin with larger themes. Therefore, in the initial stage of coding the four umbrella themes were religion and secularism; politics, rights and legislation; socio-economic and cultural integration; and tolerance, diversity and other (see Figure 2). These themes were then subdivided into smaller more specific categories afterward in order to allow for in-depth analysis within each theme and between the newspapers.

Figure 2 - Coding Scheme

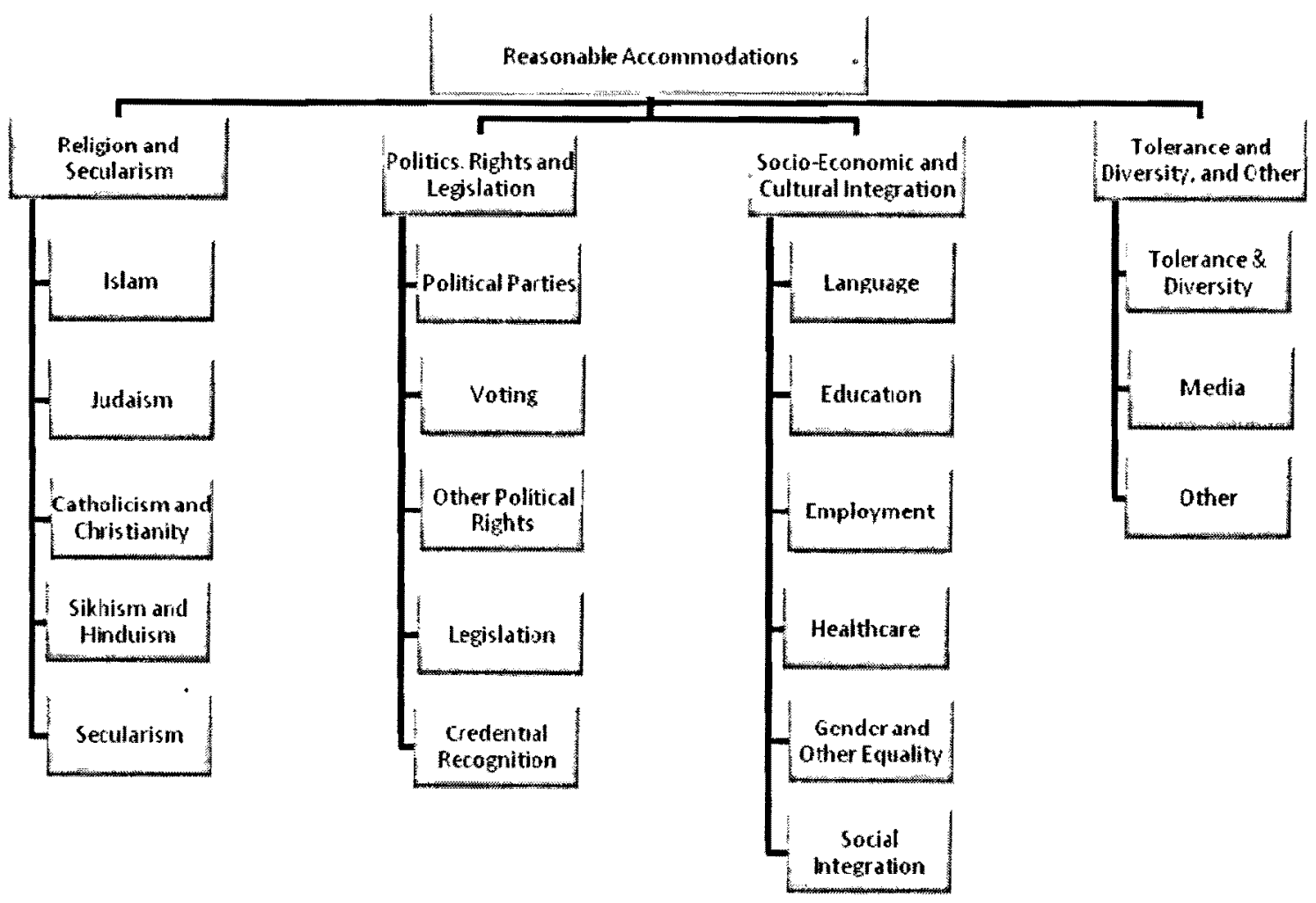


correlates with the dates where a public consultation was held or when a large organization presented a written brief to the commissioners.

$\mathrm{W}^{\mathrm{T}}$ ith the articles for further analysis determined, a coding scheme was necessary in order to determine what some of the common themes may be. Because there was very little literature regarding the idea of reasonable accommodation and therefore a lack of a model which to follow or themes known to have arose in the past, it was decided that it would be wise to begin with larger themes. Therefore, in the initial stage of coding the four umbrella themes were religion and secularism; politics, rights and legislation; socio-economic and cultural integration; and tolerance, diversity and other (see Figure 2). These themes were then subdivided into smaller more specific categories afterward in order to allow for in-depth analysis within each theme and between the newspapers.

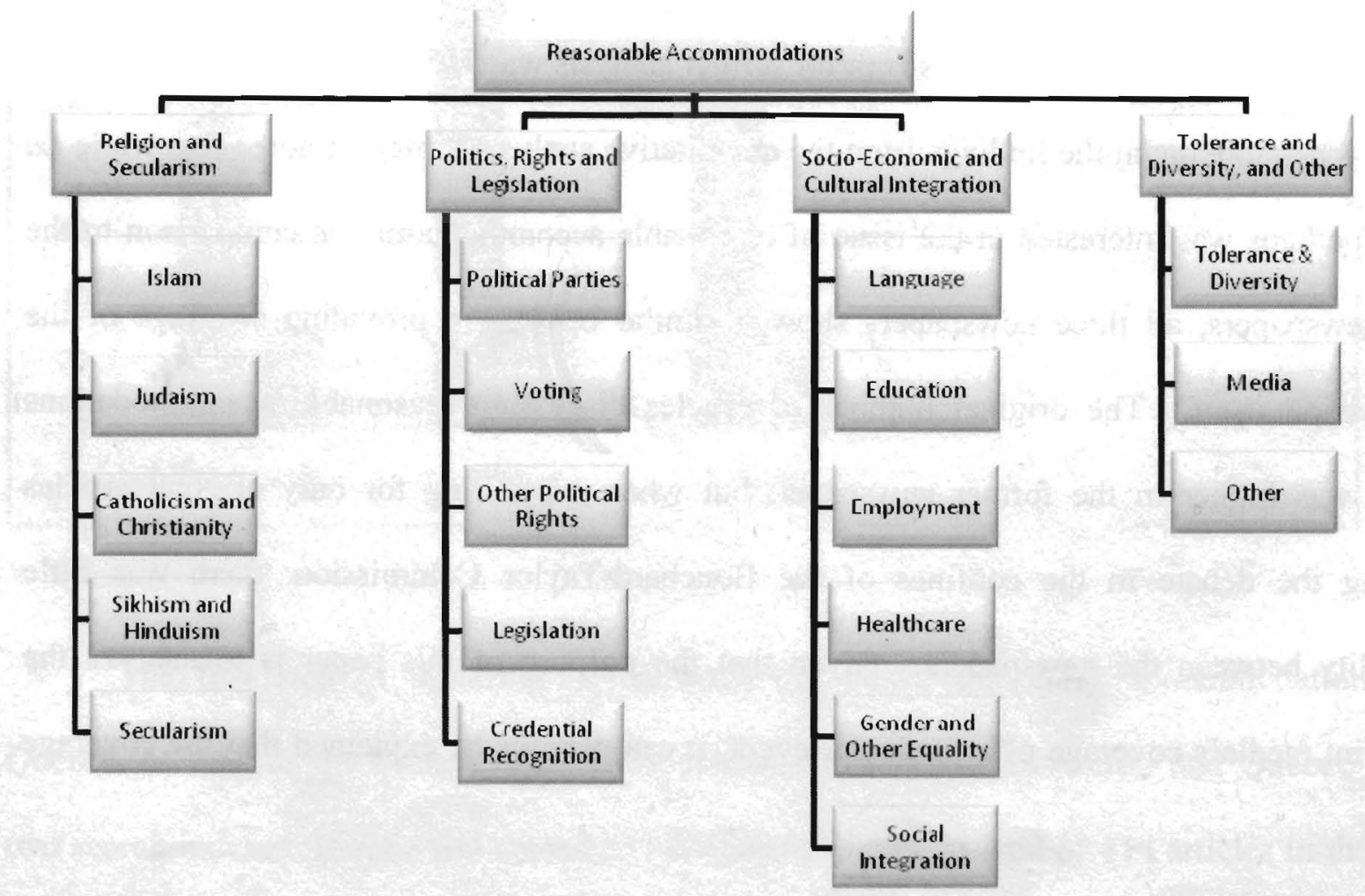


Based on how often certain themes were discussed in each paper, ignoring for now the analysis of the way in which they were discussed, La Presse and The Gazette seem to have more in common than either of them do with the coverage provided by Le Soleil. The latter newspaper discussed most themes less or equally as much as the other two newspapers with few exceptions (see Figure 3). Within the larger theme of political rights and legislation, Le Soleil discussed two subcategories more than the other two newspapers: voting rights and other political rights. In all of the subcategories within the religion theme Le Soleil provided less coverage, except when discussing issues of secularism, or laïcité, with over 10 per cent more articles than the two Montréal newspapers. The last general theme, socio-economic integration, saw some circumstances where the Québec City daily discussed particular subcategories more frequently than The Gazette but less than La Presse: education and employment.

Figure 3-Percentage of Articles Dedicated to Each Theme in the Total Coverage

\begin{tabular}{|c|c|c|c|c|c|c|}
\hline $100 \%$ & & \\
\hline
\end{tabular}


Based on how often certain themes were discussed in each paper, ignoring for now the analy'sis of the way in which they were discussed, La Presse and The Guzette seem to have more in common than either of them do with the coverage provided by Le Soleil. The latter newspaper discussed most themes less or equally as much as the other two newspapers with few exceptions (see Figure 3). Within the larger theme of political rights and legislation, Le Soleil discussed two subcategories more than the other two newspapers: voting rights and other political rights. In all of the subcategories within the religion theme Le Soleil provided less coverage, except when discussing issues of secularism, or laïcité, with over 10 per cent more articles than the two Montréal newspapers. The last general theme, socio-economic integration, saw some circumstances where the Québec City daily discussed particular subcategories more frequently than The Gazette but less than La Presse: education and employment.

Figure 3 - Percentage of Articles Dedicated to Each Theme in the Total Coverage

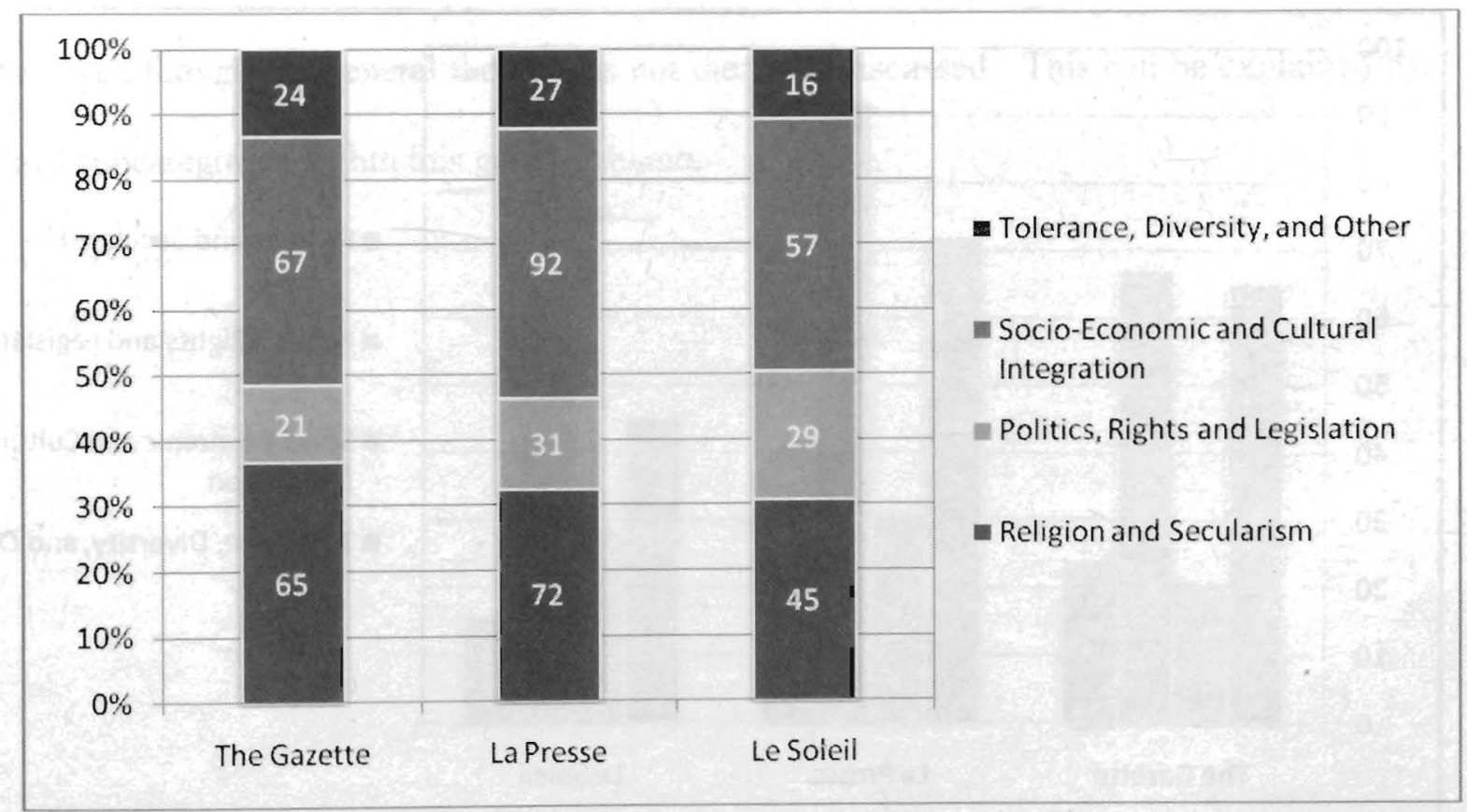


The other two newspapers were similar in most categories, particularly within the themes of political rights and legislation, and religion (see Figure 4). For example, in regards to issues of language and linguistic integration, both The Gazette and La Presse saw nearly identical coverage in terms of the number of articles covering this debate. These numbers represent over twice as much coverage of these issues as discussed in Le Soleil. This is also the case for the coverage of issues discussing the gender equality sub-theme. The two newspapers differed from one another more greatly when looking at the subcategories within the social integration theme. The Gazette published nearly twice as many articles as La Presse where discussions about the ability of immigrants to integrate socially were the theme; this number was over twice as high when comparing with Le Soleil. The sub-theme of healthcare saw very little discussion by The Gazette whereas La Presse discussed this topic over seven times more frequently.

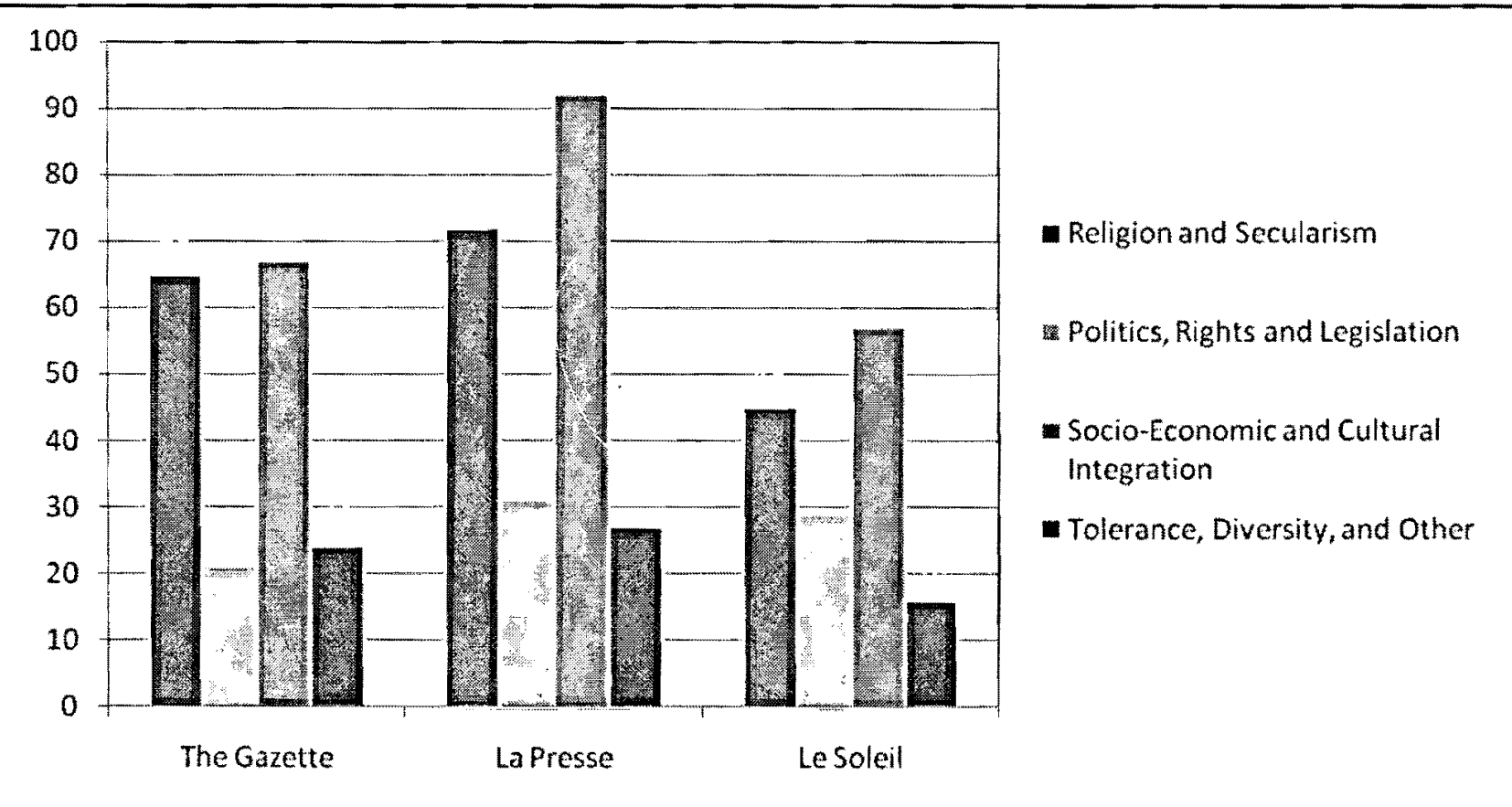


The other two newspapers were similar in most categories, particularly within the themes of political rights and legislation, and religion (see Figure 4). For example, in regards to issues of language and linguistic integration, both The Gazette and La Presse saw nearly identical coverage in terms of the number of articles covering this debate. These numbers represent over twice as much coverage of these issues as discussed in Le Soleil. This is also the case for the coverage of issues discussing the gender equality sub-theme. The two newspapers differed from one another more greatly when looking at the subcategories within the social integration theme. The Gazette published nearly twice as many articles as La Presse where discussions about the ability of immigrants to integrate socially were the theme; this number was over twice as high when comparing with Le Soleil. The sub-theme of healthcare saw very little discussion by The Gazette whereas La Presse discussed this topic over seven times more frequently.

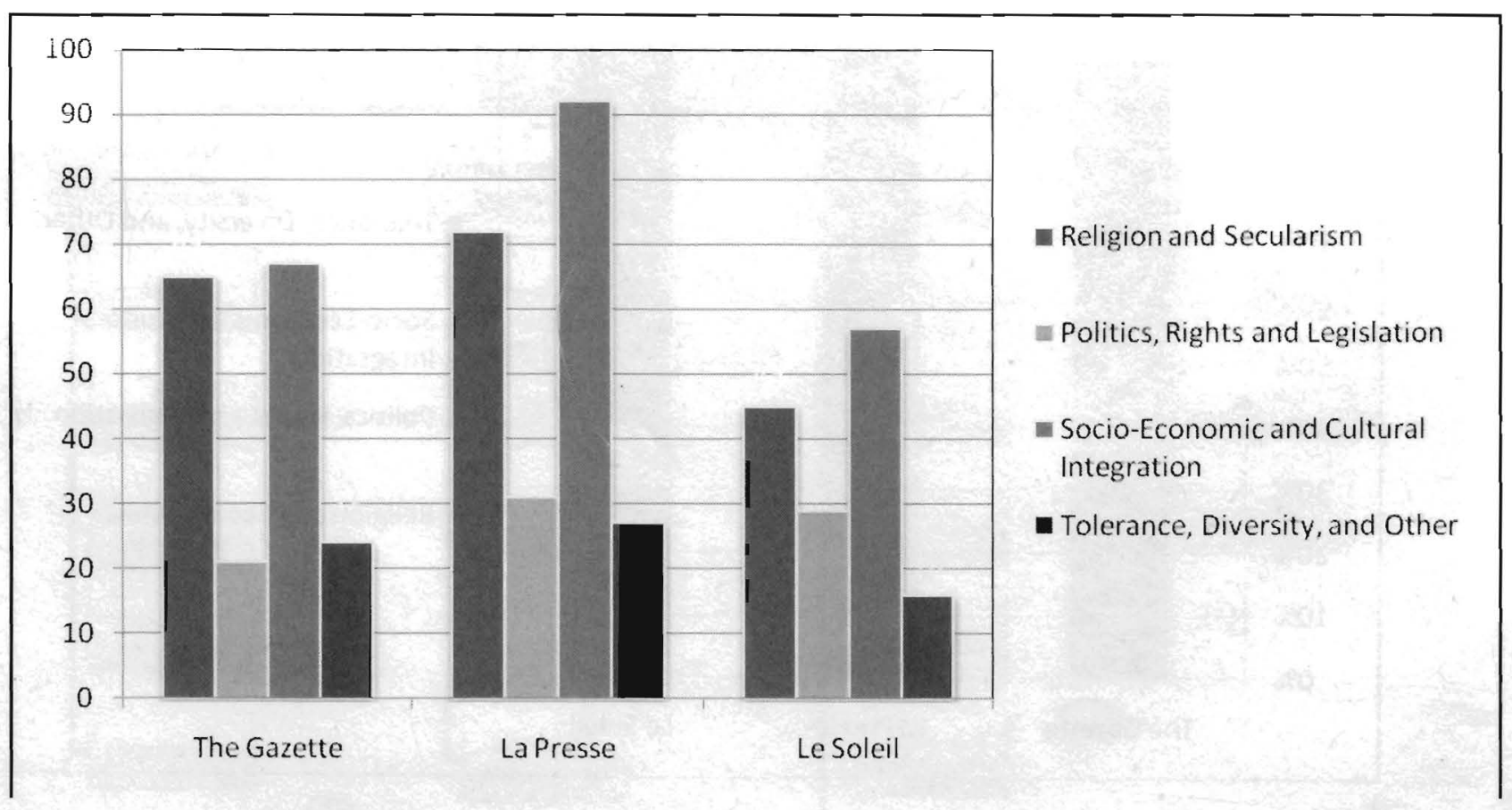


There is one particularity in terms of the frequency of codes which cannot be explained without any further investigation. Le Soleil has significantly less coverage of all themes overall than either of the other newspapers, even though a similar number of articles were found to discuss the Bouchard-Taylor Commission debates. In order to avoid themes which would remain non-coded, I created an 'other' theme for those themes which would appear sporadically with little frequency and did not fit into any of the other themes or sub-themes. Even within this 'other' category, Le Soleil showed significantly fewer occurrences.

The two general themes that were discussed with the most frequency in all newspapers were issues of religion and secularism, and socio-economic and cultural integration (see Figure 4). Within these themes, certain subcategories were discussed with more vigour than others. In the religion and secularism theme, Islam and secularism were discussed with the greatest frequency. While in the socio-economic and cultural integration theme, social integration was discussed most often. Tolerance and diversity was the subcategory with the most references; however, even though the general theme was not the most discussed. This can be explained by the lack of subcategories within this general theme. 
Figure 4 - References per Theme, by Newspaper

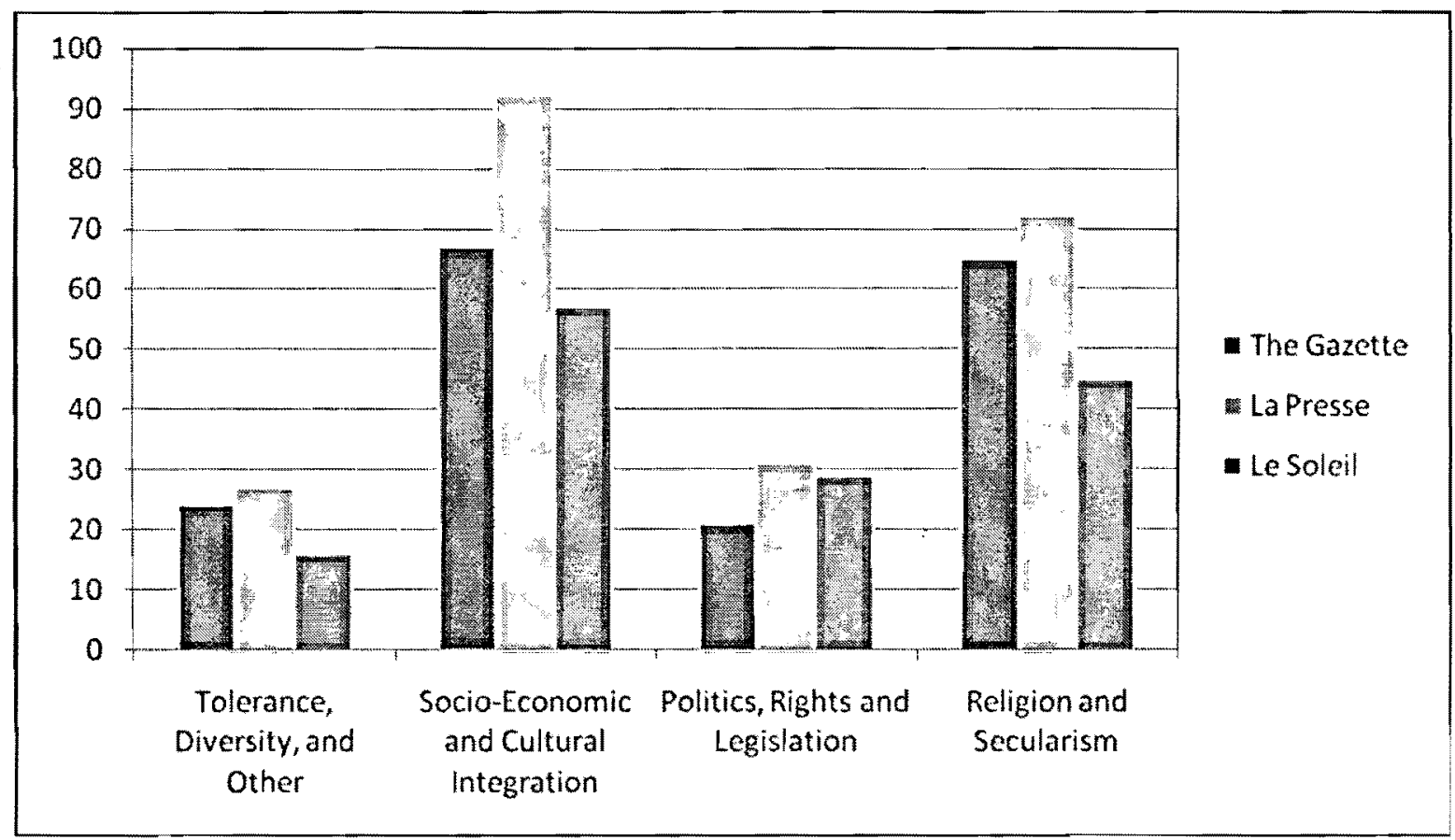

As discussed in the methods section, it would be insufficient to employ only a quantitative analysis of the data obtained from the newspaper coding. It has allowed me to understand what topics may be of greater interest to the Francophone or Anglophone communities, and of interest to the Montréal urban area or in the regions. This does not explain the way in which these topics have been discussed; the quantitative method has only shown what themes have been included and by comparing between the newspapers, which themes have been neglected by each daily. In the following section I shall discuss how these themes were discussed which shall demonstrate further differences between the three newspapers.

\subsection{Qualitative Analysis}

Quantitative analysis allows for understanding not only of the frequency of an event or occurrence, but also the content of that event or occurrence. In this way we can obtain greater 


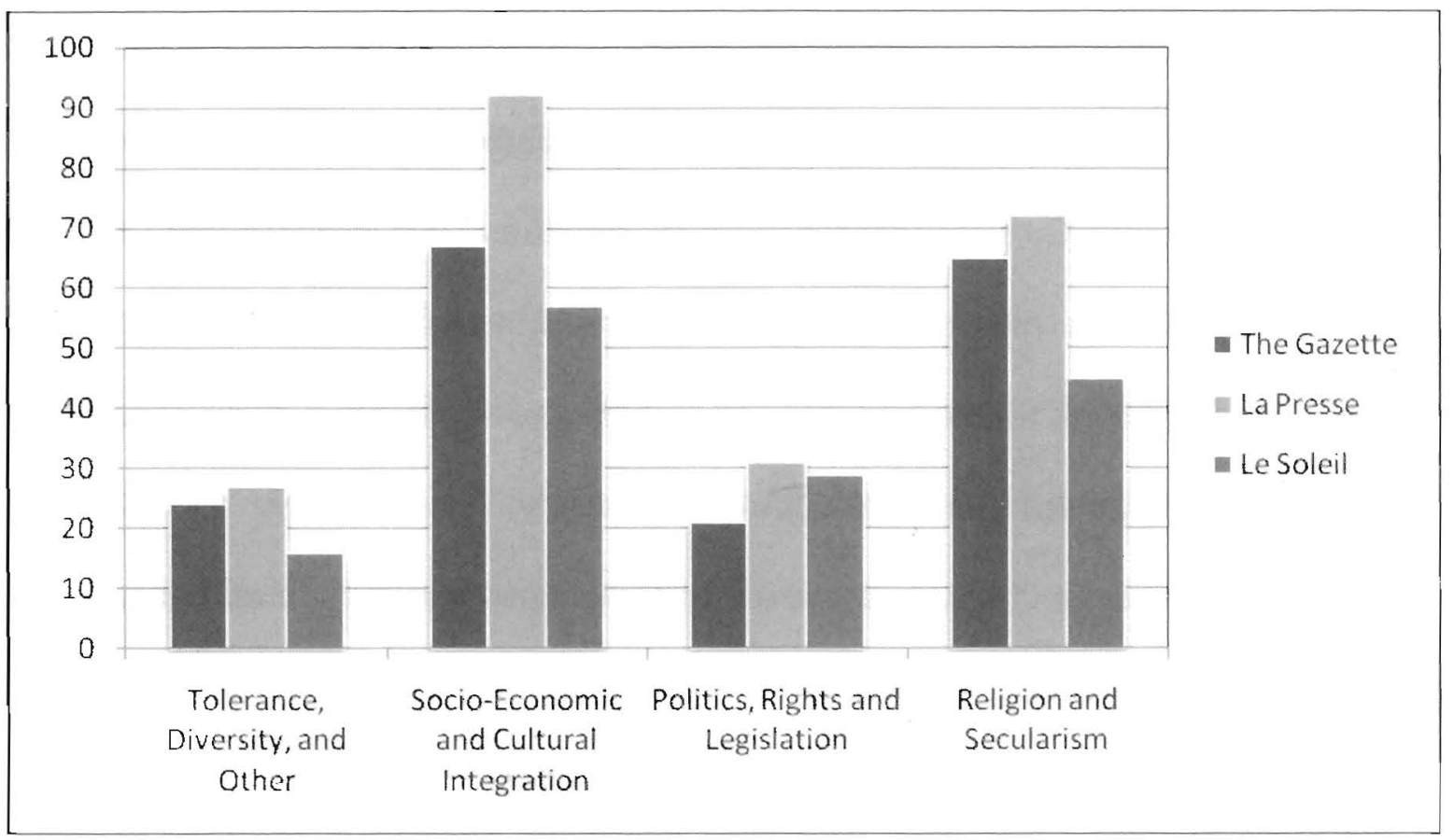

As discussed in the methods section, it would be insufficient to employ only a quantitative analysis of the data obtained from the newspaper coding. It has allowed me to understand what topics may be of greater interest to the Francophone or Anglophone communities, and of interest to the Montréal urban area or in the regions. This does not explain the way in which these topics have been discussed; the quantitative method has only shown what themes have been included and by comparing between the newspapers, which themes have been neglected by each daily. In the foliowing section I shall discuss how these themes were discussed which shall demonstrate further differences between the three newspapers.

\subsection{Qualitative Analysis}

Quantitative analysis allows for understanding not only of the frequency of an event or occurrence, but also the content of that event or occurrence. In this way we can obtain greater 
information about the phenomena being studied and a more accurate explanation can be provided of what it is that is being studied. Here I shall elaborate on the results highlighted in the quantitative section of this paper, and provide some insight in regard to how immigrants were being discussed in the context of these newspaper articles (Mayring, 2000; Cresswell, 2009).

\subsubsection{Religion and Secularism}

Religion and secularism was one of the themes discussed the most often and with some of the most extreme opinions. More specifically, Islam was the religion most often attacked, although persons practicing the Jewish or Sikh faiths were not excluded from the debate. Overtly, participants at the Bouchard-Taylor Commission expressed fear of an increase of religious accommodations requests upon the state and the influence of Islam on Québec society as a whole. At the Commission hearing held in Laval in November 2007, one mother expressed her fear in regards to educators being permitted to wear religious dress;

Children are sponges, and if my children are taught by someone (who is Muslim), they'll start asking themselves who they are [...] And since I'm trying to be open with them, they risk being influenced by someone with a stronger religious identity who's with them all day." 4

Of all references made to Islam in The Gazette, approximately one-third of all quotes were overtly intolerant, or based in ignorance or prejudice. The article from which the quote above was taken dedicated fifteen per cent of the word count to the fears of this one mother. In addition, the same article included the comments of a participant who listed Muslims at the bottom of the list of 'preferred' immigrants, behind "Latinos and Haitians and Asians [who] know how to be part of the Québec melting pot" ${ }^{15}$. Even further, in a separate article, a Jonquière

\footnotetext{
${ }^{4}$ Heinrich, J. (2007, Nov. 15). Mother considers teachers in hijabs a threat; Concerned over 'bath of cultures'. Accommodation hearings continue in Laval. The Gazette, p. A7

${ }^{5}$ Ibid.
} 
man was quoted, "Are we going to tolerate foreigners who come here and impose the burqa? ... If you don't like it, you can go home." 6 Very few (just over 1 in 10) references portrayed Muslims in a positive light, and just as few criticized media, politicians and other actors who have contributed to the portrayal of Muslims in a negative way.

Le Soleil and La Presse included coverage of opinions that were far more critical of those who spoke against minority religious groups. This does not mean that these papers were not guilty of including commentaries or quotes that were overtly racist or ignorant along the same vein found in The Gazette; only that these newspapers provided more balanced coverage of the diverging opinions expressed at the Commission. Some coverage overlaps between two or even all three of these newspapers, particularly some of the most shockingly discriminatory ones or stories of lived discrimination. Nearly half of the references to Islam in both French newspapers either criticized the media for their portrayals of Muslims in a negative light or criticized those who argued in favour of a ban on the hijab in the name of gender equality. Following the November $26^{\text {th }}$ public consultation in Montréal, Le Soleil dedicated an entire article to a retired political science professor's comments blaming the media for spreading false representations,

Ceux qui s'affolent son ceux qui ont accès à ces phénomènes par le biais des médias, et non ceux qui les vivent. L'expression du soi-disant malaise vient d'endroits où il n'y en a pas de problème. Hérouxville, où le débat a commencé l'hiver dernier, en est un exemple. Alors, si on se demande pourquoi les gens d'Hérouxvilie sont mal à l'aise, on est obligé de répondre: 'Parce qu'ils regardent la télévision.' C'est aussi simple que ça [...]. On voit rarement des femmes portent la burqa à Montréal, mais on en voit beaucoup à la television, et de loin, il est facile de s'imaginer que Montréal peut finir par ressembler à Kaboul. ${ }^{7}$

\footnotetext{
${ }^{6}$ Heinrich, J. (2008, Sept. 20). Flood of immigrants feared; Hearings in Saguenay. Secular society, Roman Catholic heritage in peril, Taylor-Bouchard commission told. The Gazette, p. A8.

${ }^{7}$ Cliché, J.-F. (2007, Nov. 27). "Quel malaise?" demande Louis Balthazar. Le Soleil, p. 8.

Translation : Those who are in a panic are those who obtain information about such phenomena through the media and are not those who live them. The expression of the so-called unease live in areas who do not have any of these problems. Hérouxville, where the debate commenced last winter is an example. So if we ask why people in Hérouxville are uneasy, we must answer 'that it is because they watch television'. It is as simple as that... We
} 
This quote demonstrates some of the frustration felt towards the media that would have the population believe that immigration, particularly of certain groups such as Muslims, is problematic. The professor who made this statement shows his opposition to fear mongering that portrays both Muslims in a negative light elsewhere, and then paints Muslim newcomers with the same brush, hence contributing to a moral panic ${ }^{8}$ where immigrants are a group to be feared. Most of the literature reviewed earlier discussed the concept of moral panics to some extent, without necessarily using that term, and how the media through biased and discriminatory portrayals of certain groups can lead to the sense that the status quo is being threatened (Todd, 1998; Esses et al, 2001; Li, 2001; Mahtani, 2001; Helly, 2004; Greer and Jewkes, 2005; Jiwani, 2005; Cisneros, 2008; Nieguth and Lacassagne, 2009; Wortley, 2009). Of the eleven articles where Islam was discussed within the coverage of the Bouchard-Taylor Commission in Le Soleil, only two entire articles were dedicated to the voices of those who spoke out to defend Muslims and challenge the stereotypes that had been made public to that point.

As with most topics or themes, there is not a dichotomy of opinions but rather a range from one extreme to the other. La Presse provided such coverage more so than the other newspapers, including articles not only either for or against religious accommodation, nor articles that either challenge or explain the discourse. There were several articles which both challenged the understanding of religious minorities and accommodations through the propagation of the stereotype proposed in the media and elsewhere,

"Déçus par le Québec, des immigrés musulmans se radicalisent dans les mosquées. Et ce n'est pas seulement de leur faute. 'C'est la faute de nos structures d'accueil incapables de répondre aux besoins de ces gens.' Et

rarely see women wearing burqas in Montréal, but we see many of them on television, and it is not so hard to imagine that Montréal may one day look like Kaboul.

${ }^{8}$ Term coined by Cohen (1972), which means "a condition, episode, person or group of persons [who] become defined as a threat to societal values and interests" (p. 9). 
s'il y a des mariages forcés dans certaines communautés installées au

Québec, c'est aussi parce que le Québec intègre mal ses immigrés."9

This quote, elaborated on following the public consultation held in St-Jérôme, north of Montréal, was made by a social worker in the region who assists newcomers to integrate. The majority of the article was dedicated to her understanding of the integration problems that immigrants face, and how in turn this leads to other problems such as a sense of exclusion on behalf of the immigrant as well as misunderstandings between immigrant and host communities, therefore greater acceptance and understanding of diversity is required. At the same time, this quote is problematic as it assumes that practices not traditionally part of Québec's culture are inferior or backwards. La Presse dedicated the majority of an article to this discussion, elaborating on the challenges of newcomer integration in the region, while neither of the other newspapers mentioned the attendance of this social worker who had much knowledge to contribute.

The most common debate regarding religion mentioned during the Bouchard-Taylor Commission had little to do with how to accommodate the religious accommodations requested, but rather whether such accommodations should take place at all in public institutions such as schools and the civil service given the secular nature of the state. A variety of suggestions were proposed in terms of how to proceed in this regard, all of which would have effects on newcomers who belong to minority religious groups.

\footnotetext{
${ }^{9}$ Touzin, C. (2007, Sept. 26). Le Québec "intégre mal" ses immigrés. La Presse, p. A10.

Translation: "Disappointed by Québec, Muslim immigrants are becoming more radical through their mosques. And it is not only their fault. 'It is the fault of our reception structures which are incapable of assisting them in their needs.' And if there are arranged marriages in certain communities in Québec, it is also because Québec integrates poorly its immigrants."
} 


\subsubsection{Socio-Economic and Cultural Integration}

Under the umbrella theme of socio-economic and cultural integration, there were several themes discussed which were expected given the day-to-day debates that have existed in Québec for decades: language and social integration. Perhaps it is because Montreal is the most diverse city in the province and the main reception centre for immigrants to the province that both of these themes were more widely written about in The Gazette and La Presse in comparison to Le Soleil. The latter category overlapped with several other categories, and therefore I shall elaborate only on the language category. In the latter newspaper, language was only mentioned eleven times in the entire period of the coverage of the Bouchard-Taylor Commission. In over half of those references, language was mentioned as part of a list of Québec values or cultural characteristics that are essential to protect. In these articles there was no direct mention as to whether there was a greater need to select immigrants on the basis of French-language skills, or to provide improved language training to newcomers. The remainder of the articles included proposåls on how to improve linguistic integration, without overtones of fear of immigrants as a threat to the survival of the French language in the province. Only one article quoted a Jonquière man who spoke directly to this fear, "La crise des accommodements résulte de l'insécurité ressentie par les Québécois à l'égard du français"'10. In essence this quote states that the entire reasonable accommodation debate is the result of linguistic insecurity felt as a result of increased immigration, and that immigrants must be encouraged to acquire higher levels of French language competencies.

The Gazette's references to language had less to do with covering what was said in the presentations before the Commission and more to do with which language the presenters spoke.

\footnotetext{
${ }^{10}$ Giroux, R. (2007, Sept. 12). Le débat religieux à l'avant-scène. Le Soleil, p. 7. Translation: "The accommodation crisis is the result of the insecurities of the Québécois in regards to the French language."
} 
Le Soleil did not mention what language a presenter spoke, including when the participant spoke a language other than French. On the other hand, The Gazette highlighted much more frequently the language spoken by a participant in the Commission when it was a language other than French, and kept count of how many such presentations took place. This newspaper included some harsh comments made by participants at the Commission against those who do not speak French, proposals for discriminatory legislation, and some of the consequences faced by newcomers who do not speak the official language of the province sufficiently. There was only one article that offered a historical explanation as to why the Québécois fear certain 'types' of immigrants; as mentioned in the demographics section of this paper, prior to Québec obtaining control over immigration destined for its territory, most newcomers integrated into the Anglophone community, and this situation has only recently changed. While this may appear to be an unfounded or irrational fear, as well as one based potentially in discrimination, it is viewed as a very real threat in the province.

Not only did La Presse provide greater coverage than Le Soleil in terms of the number of articles where the language theme was found, but it also offered a greater variety of coverage in terms of opinions than The Gazette. Like the other two newspapers, there was some reporting on those who view many immigrants as a threat to the French language in the province and the Québec nation, as well as discriminatory comments towards those who do not speak the language; this represented a minority, only five of over thirty references. Unlike the other newspapers, La Presse included discussions regarding the right to interpreters, as well as the challenges and problems faced in the healthcare system and other public institutions used by those immigrants who do not speak French and perhaps have limited English skills as well. Also included were some articles which made reference to linguistic integration success stories, the 
need to reinforce or modify existing language laws, and some suggestions regarding ways to improve language courses and the overall French-language ability of newcomers.

\subsubsection{Tolerance, Diversity, and Other}

Under the theme of "tolerance, diversity and other" the media category received little discussion, but it is directly relevant to the topic of this research study and hence its inclusion in the analysis here. Most articles included discussions of media portrayals of immigrants and had in common that these portrayals play a negative role in contributing to the discourse. Media portrays immigrants, religious and visible minorities in a stereotypical way and upholds the status quo, rather than challenging existing stereotypes. The aim of the private, mainstream media is to maximize profits like other private corporations, and therefore must sensationalize the subject of immigration to ensure increased readership and profits. The coverage of the Bouchard-Taylor Commission within the media was criticized primarily for its one-sided portrayal of Muslims, and this was the case in all newspapers, as can be seen in quotes such as the following,

Faut-il vraiment, au nom de la démocratie, écouter des âneries que l'on condamnerait autrement, du genre: "Je suis obligé d'endurer les musulmans." Le genre de propos que tout journal responsable refuse de publier dans ses pages du courrier des lecteurs. ${ }^{11}$

Both The Gazette and Le Soleil discussed the media's role prior to the commencement of the Commission with little coverage of the comments made by participants regarding the media coverage of the Commission itself. In this regard, La Presse differed significantly. Not only did this newspaper quote participants more often in regard to the criticism of media portrayals of

\footnotetext{
${ }^{11}$ Marissal, Vincent (2007, Sept. 13). Le "freak show". La Presse, p. A7. Translation: "Must we really, in the name of democracy, listen to this garbage that we would normally condemn, in the vein of ' $I$ have to endure Muslims'. This is the type of sentiment that all responsible newspapers refuse to publish in their letters to the editor section.
} 
minorities within the framework of the Bouchard-Taylor Commission, but it also dedicated entire articles and editorials criticizing these portrayals. Because these latter articles did not directly report on the occurrences of the Commission they were not included in my analysis for this paper, yet I thought it interesting to mention here that this newspaper dedicated a fairlyregular column to criticize media coverage, including its own. As Li (2001) states overt racism in discourse is inconceivable in a democracy, and hence a possible explanation for the lack of references which could be coded in this theme.

The last theme I shall discuss here is the one that all three newspapers mentioned the most often. It is also the theme that had some of the most varied type of comments with some of the most positive coverage and quotes, as well as some of the most negative and prejudicial: the tolerance and diversity theme. This theme also has the most articles which include quotes or coverage of the opinions of newcomers and minorities themselves. As some have alleged, the media has provided coverage of some overtly racist or discriminatory language, which was discussed briefly in our analysis of the media theme. When 1 use the term overt, I mean that the newspapers have provided a direct quote or comment where a participant stated a discriminatory opinion where an entire group of people was portrayed in a stereotypical manner. The Gazette included these direct quotes most often, more than twice as often as the two French newspapers, for a total of seven references in this newspaper alone. What is rather interesting is that in all newspapers there are more references to comments made accusing the Bouchard-Taylor Commission of giving a medium for racists to air their grievances than there are quotes that are overtly racist.

Often included in this theme were personal anecdotes given by newcomers and individuals belonging to other minority groups who spoke to the discrimination they have faced 
in their day-to-day lives both prior to and since the debate on reasonable accommodations in the province began. The group who spoke the most to this effect, according to all three newspapers were Muslims, both native and foreign-born. These testimonies come into direct contradiction with those comments made in favour of diversity and acceptance, particularly those participants who spoke as though no tensions between the majority and various minority groups existed. Unfortunately, the number of commentaries and quotes made in support of existing or greater diversity were represented in only fifteen per cent of all coverage of the reasonable accommodations debate, with only nineteen references in all three newspapers pushing in favour of greater acceptance for either immigration or reasonable accommodations. Here were some surprising results given the findings in the other themes. In the case of how much coverage was provided regarding calls for greater diversity, The Gazette had the highest number of references, with seven articles dedicating a portion of each article to this theme. Le Soleil and La Presse had an equal number of six references in favour of greater diversity and acceptance, which translates overall to La Presse having the lowest proportion (16 per cent) of articles where this theme was included, and Le Soleil having the highest proportion (19 per cent). As can be seen from these numbers there was only a slight variation between all three newspapers.

Most comments made by participants with a discriminatory tone were less overt. Instead, participants taking the microphone at the Commission used language of fear and stereotypes. Terms such as malaise, which translates to 'unease' in English was used relatively often, and can be seen as a word which is not as harsh a term perhaps as fear, discomfort, or unwillingness. An example of how this term was used to describe one's feelings of fear towards certain minority groups, while avoiding overtly discriminatory terms was given by Bloc Québecois leader, Gilles Duceppe, who said he felt, "mal à l'aise avec les habits qui empêche 
l'identification, comme la burqa et le niqab". ${ }^{12}$ This same observation about the use of more politically-correct language was highlighted by an activist belonging to the group No One Is Illegal (a group advocating for status for all persons) during one of the public consultation sessions held in Montréal,

The very assumption that immigrants need to be informed of values such as equality of the sexes assumes and implies that immigrants have a lesser ability to understand basic principles of 'vivre ensemble'. And in that sense it's racist because it assumes [immigrants] are uncivilized, backwards. ${ }^{13}$

By masking racist language in the guise of 'malaise' such opinions as the one expressed by Mr.

Duceppe are rendered acceptable and even valid as it can be argued as a legitimate concern rather than stereotyping or discrimination. Many of those comments which propagated stereotypes or used covert discriminatory language would have been excluded from this theme, as here my goal was to analyse that language which was overtly racist and did not require subjective interpretation in order to determine whether language was discriminatory. However, to assume that the effects of such discourse are less damaging would be inaccurate.

\section{Discussion}

As proposed by Fairclough (1995), when analysing media discourse it is important to take into account several factors such as language, social context, as well as to acknowledge what information has been excluded; it is imperative to look at the whole picture instead of doing only a linguistic analysis, for example. A linguistic analysis in this case in particular would provide an unclear understanding of how immigration and immigrants were portrayed in the media discourse since we are analysing newspapers of different languages, and that certain

\footnotetext{
${ }^{12}$ Cliché, Jean-François (2007, Dec. 12). Accommodements raisonnables: Duceppe ouvert aux signes religieux dans la function publique. Le Soleil, pp. 11

${ }^{13}$ Mennie, James (2007, Dec. 11). Moral commitment document doesn't mention our problems; "Information on poverty and lack of access to health care might be useful." The Gazette, pp. A4
} 
words do not translate in exact terms, or may not hold the same social or cultural meaning. Without analysing the social context from which the language stems from only a partial understanding of the overall meaning is clear.

In the background sections, I highlighted some details of the immigration demographics in Québec in addition to some of the history and structure of the reasonable accommodations debate and the resulting Bouchard-Taylor Commission. Throughout this section I will draw on some of this information as well as insert additional explanations to help understand some of the comments made at the Commission as well as why one newspaper may have selected to include certain information and not other details. Before continuing any further, much of the coverage and quotes do not point the finger directly at immigration or immigrants. In Québec though, much like elsewhere in the world, visible and other minorities are viewed as 'other', as immigrants would be considered, whether that be the case or not (Greer and Jewkes, 2005; Fall and Vignaux, 2008). Therefore, the discussion of such minorities in these newspapers is pertinent to this discussion as I am trying to understand how the Québécois view who they define as immigrant or 'other', and how the newspapers covered this debate.

When discussing the results listed above in terms of relationships or correlations, it would seem that certain topics are perhaps of more interest to Francophones and others may be of greater interest to those living in the Montréal urban area. For instance, Le Soleil provided less overall coverage of the Commission itself, and less coverage of all themes except for one: secularism. Perhaps in the regions where reasonable accommodations for religious minorities are not an everyday occurrence, the debate over how secular the state and its institutions should be is of greater significance. The quantitative analysis alone would lead to some misinterpretation however in certain circumstances. While the two Montréal newspapers showed 
similar interest in the language theme in terms of the number of articles discussing this subject, the two Francophone newspapers show more resemblance in terms of content, which shall be elaborated on later in this section.

There are other topics where no clear relationship appears to exist as the number of articles discussing a specific theme or subcategory is higher for only one newspaper, or where all newspapers provided similar coverage. An example would be healthcare, a category which fell under the socio-economic and cultural integration theme. Here La Presse demonstrated a far greater interest in this topic than did either of the other newspapers. Does this mean that this newspaper covered the debates in greater depth, or that the journalists from the other newspapers did not report on a greater range of issues that were raised at or presented to the Commission? Let me elaborate on why certain themes may be of greater interest to be discussed in the media discourse as a whole, or why a given newspaper is attracted to one theme within the greater debate, based on its target audience or the group with which it identifies.

\subsection{La nation québécoise (The Québec Nation)}

The goal of finding a means to allow for greater integration of newcomers and minority groups, as was the purpose of the Bouchard-Taylor Commission was and is to allow for a more harmonious Québec nation. Commissioner Bouchard (1999) himself has written on this subject rather extensively in his career. He views the concept of la nation québécoise as not a fixed identity, but rather one that is in flux as well as is in need of more change. Traditionally, the idea of a Québec nation was one based on ethnicity, religion, and history; the Québécois were viewed as Francophone, Catholic, and have in common that they had colonized the territory of New France. Bouchard argues that this traditional view is both false and in need of further change to 
reflect the diverse history and increasing diversity of the province. The change towards a pluralistic view began at the beginning of what is known as La révolution tranquille. ${ }^{14}$ However, a civic concept of the nation would not be any more viable in the Québec context, as it is too individualistic and does not allow for a collective Québécois identity. Therefore, la nation québécoise is and should continue to progress towards a more inclusive definition of 'us': a French-speaking society (in the public sphere) comprised of a plurality of ethnicities and histories including First Nations, Anglophones, and newcomers. There are still advocates of each definition of this collective identity or nationhood, and hence some of the difference in how immigrants are viewed, either as a threat or as 'one of us'.

\subsection{Religion}

When attempting to understand why people would view the place of religion in our society in a specific way or how they view religious minorities, the majority of which are viewed as being immigrants, we must investigate certain elements of Québec culture and history. Until the 1960s the province was predominantly Catholic. The Church was responsible for providing public services that were regulated in other provinces by their respective governments such as education and welfare services. The economy was controlled mostly by English-speaking entrepreneurs who employed French-speaking Québécois in low-skilled and low-paying jobs. Eventually tired of working for the English 'other', the population decided it was time to take control over their collective well-being, which included rejecting the Church as it was viewed as one of the institutions that had helped keep the Québécois in a position of subservience. The Church had for generations encouraged large families and that people be content with their lot, however

\footnotetext{
${ }^{14}$ The Quiet Revolution, which took place during the 1950 s and 1960 s, was a period of modernization and secularization in the province of Québec, in both the public and private spheres.
} 
simple their lives may be. While the promotion of large families had allowed for French Canada's population to grow at exponential rates, it prevented economic growth in the hands of this population who often lived in more rural areas on family farms or working factory jobs in the city and living in cramped dwellings (Kelley and Trebilcock, 2000). Yet, while most Québécois no longer consider themselves to be 'practicing' Catholics, the religion is an important part of the history and cultural practices of province, and hence key to the traditional definition of la nation. Any discussion about the place of religion in public life would be a 'hotbutton' topic, but when discussing the place of other religions an added dimension comes into play.

Given the number of references against religious accommodation, as well as the number of people who made legislative and other suggestions either in favour of secularism or in protection of Québec's Catholic heritage, it would be appropriate to discuss the ramifications of some of these proposals made before the Commission. Currently, the freedom of religion is enshrined in the Canadian Charter of Rights and Freedoms as well as the Québec Charter of Human Rights and Freedoms (Bouchard and Taylor, 2008). If a religious accommodation were refused or if the province were to pass legislation placing limits on religious practice, there would be recourse for those seeking to protect their religious rights, and hence it would be difficult to elaborate on how immigrants would be affected based on such suggestions.

This was the case when Supreme Court of Canada ruled in favour of allowing a Sikh student to be permitted to wear a kirpan to school, as was mentioned in an earlier section of this paper. Immigrants would not be the only group affected by any such legislative or other changes, as not all religious minorities are newcomers. However, as immigration increases the diversity of the province, and demands for reasonable accommodations based on faiths other 
than Catholicism, any such legislative or other challenges in favour of reasonable accommodations may be viewed by the Québécois to be a negative and unnecessary consequence of the presence of immigrant "others'.

\subsection{Language}

There were significant differences in the way that newspapers discussed linguistic integration of newcomers and language overall, with Le Soleil provided little coverage, The Gazette portrayed Québécois as discriminatory on the basis of language. As well, La Presse covered varying aspects of language not covered by the other newspapers such as access to healthcare and interpreters, as discussed in the findings sections. Important to this research is the question: Why do such differences in coverage regarding the linguistic integration of immigrants occur? Historically, newcomers have integrated into the English-speaking community in and around Montreal rather than into the French-speaking community in the city or elsewhere in the province. This is partly because prior to the 1970 s language laws such as La loi sur la langue officielle (Bill 22) and La charte de la langue française (Bill 101) did not exist and Québec did not have control over the selection of immigrants destined for its territory. English was and is often referred to as the 'language of business', and this was the case in Québec prior to the passing of official language laws. Therefore it was more beneficial for newcomers to learn English rather than French in order to secure employment while still receiving government and other public services in English. These factors in conjunction with decreasing birthrates in the province led to French decreasing in importance, and left the Francophone majority fearing for their survival (Kelley and Trebilcock, 2000). 
Since the adoption of French as the official language of the province in 1977 the children of newcomers have been obliged to attend French primary and secondary schools with few exceptions, such as those who opt to send their children to private institutions where the language of instruction is then chosen by the parents. As a result of such language laws, there has been an increase in the integration of newcomers into the French-speaking community. In 1990, the Canada-Québec Accord granted the province control over the selection and integration of all newcomers. As a result priority has been given to those newcomers who already have knowledge of French (Québec, 1990). Furthermore, because immigration applicants are required to submit a separate application to the provincial and federal governments, it is assumed that newcomers have a greater understanding of the society into which they are integrating and not that they are simply moving to one of the Canadian provinces.

As discussed in the literature review earlier in this paper, Todd (1998) argues that because of the different cultural psyche of the English and French communities, the news media of each will reflect the fears and worries of their respective communities. Over the last several decades, it is the Anglophone community which has been feeling threatened as a result of its dwindling numbers in the province. Many Anglophones have out-migrated to other provinces, the birthrate has fallen to below replacement level, and newcomers are no longer permitted to enter the English public school system. According to Todd's logic, it is possible that the continual references to the language spoken at the Bouchard-Taylor Commission found in The Gazette may be due to the threat of disappearance the Anglophone community feels. Many of the articles also quoted some of the more shocking and prejudicial comments made by some of the French-speaking participants while not giving any possible explanations and without including any such quotes made by non-French speakers. Todd's argument is that The Gazette 
often portrays the Francophone community in such a way as a means of attacking that community by which they feel threatened.

Helly (2004) argues, after conducting her own content analysis of Canadian newspapers covering stories following the September $11^{\text {th }}$ attacks regarding immigration, that French newspapers more often than English newspapers attempt to provide more background on a given story. This may explain why La Presse has been more balanced in its coverage of this issue, writing articles discussing issues which went unnoticed by The Gazette. While there is no explanation found in the literature as to why Le Soleil was less interested in this theme than the other two papers, I suspect like many of the other themes, it is one which affects the community outside of Montréal less. It is also perhaps because those immigrants who do settle in the regions do and have traditionally integrated linguistically into the Francophone community because of the lack of any other linguistic communities in those areas of the province. Therefore, immigrants are not viewed as a challenge in terms of integration or threat to the linguistic makeup of the province.

\section{Conclusion}

Let me reiterate my initial research questions here in order to determine what has been learned as well as where future research is needed. What is the extent of the difference in the media discourse between different media outlets? There are some slight differences in certain areas, such as the politics and legislation theme; there are more pronounced differences in others themes such as language. Helly's (2004) findings that French-language news-media tends to be more critical in its coverage of an event as well as provides greater analysis would appear true in the case of La Presse, but this not true when comparing the other two newspapers to one another. 
The former paper provided discussion on a greater variety of issues raised at the BouchardTaylor Commission, but the differences between the other two newspapers are less significant and do not support Helly's arguments. Overall however, all three Québec newspapers included far more negative stereotypes about immigrants and fears of what immigration might do to the existing culture and other characteristics of the province and its people. I have argued that all three newspapers portray immigrants and other minorities requiring some level of reasonable accommodation in a negative way, and that very little attention has been paid to dissenting voices arguing in favour of equality and greater openness to diversity, regardless of which newspaper one looks at.

How do competing media discourses affect the overall public discourse? Further research needs to be done in this area to know what the specific effects are of media on the public discourse regarding the reasonable accommodation of minorities. As highlighted in the literature, media is a strong influencing force on public discourse in general. The effect on public discourses exists even when media either misrepresents or under-represents minority groups (Mahtani, 2001), or when covertly discriminatory language is used (Li, 2001). Even in a province like Québec with a relatively small population in comparison to other 'nations', as the Québécois often view themselves, there are competing media sources. The three newspapers selected for study here cater to three relatively different populations: Anglophones and Francophones from Montréal and the other fifteen regions of the province, each having distinct cultures and varying opinions on the issues raised at the Bouchard-Taylor Commission. Each of these populations surely has their own different public discourses as can be seen through the variations between their representative news sources with their competing discourses. Todd (1998) in her discussion of media coverage in Québec regarding the right of Muslim girls to wear 
the hijab in school and other public institutions, shows that indeed there is no one public discourse in the province, and hence there are varying media discourses representing each of these public discourses. Thus, each public discourse is affected by various competing media discourses, but is likely most influenced by that media discourse with which one most identifies. Further research is necessary in order to analyse more fully how each media discourse reflects the public discourșe of the population which it targets for its readership, and how it represents this readership in its reporting versus how it represents those it views as 'other'.

How may public discourse shape the media discourse in turn? Public discourse is not simply the discourse held by the majority of the population; it is those discourse held by any individual or group of individuals in society. Therefore public discourse in relation to reasonable accommodations can be that discourse used by politicians when giving a press conference to the statement provided to the Bouchard-Taylor Commission by an association representing a special interest, or minority, group. Thus when such groups or individuals contribute to the discussion they often affect media discourses as they are viewed as experts or those with enough power to contribute to the mainstream media discourse. Not all contributors to public discourse are equal, where politicians and other public figures often hold greater power than individuals, for example.

The media often reports on public discourse such as public consultations and public opinion polls for example. When the media reports on public discourse it is being shaped by this discourse on which it is reporting. In turn, the media chooses what it wants to report, and what it chooses to ignore. Even within the same medium in the same province it can be seen that different media outlets provide different coverage. Certain newspapers covered different aspects of the Commission in greater depth than others, and used different language in order to describe or criticize the same occurrences. However, all of the newspapers were reporting on a public 
discourse which existed prior in the province, even if much of this discourse had already been influenced by earlier media reports. Had the Bouchard-Taylor Commission not taken place, or had been held in a different format that did not involve public consultations, the media would not have had anything to provide coverage of. The relationship between media and public discourses therefore appear circular in nature.

Is there a disconnect between media and public discourse? There must be a disconnect between the media and public discourses, for if the media truly reflected the existing public discourse, or vice versa, we would see virtually identical reporting of such a specific event between all three newspapers analysed, even if the debate itself if not unified. In this case there are two possible explanations: either each media discourse is accurately reflecting the public discourse with which it identifies (i.e. each newspaper is reporting on the discourse of its target audience) or at least two of the three newspapers studied do not accurately reflect the public discourses within the Bouchard-Taylor Commission debate, as if any of them accurately represent all the discourses found at the Commission then at least two are not accurate otherwise all three newspapers would show similar findings. It would be difficult through the method of content analysis to study what differences exist between these two discourses, although further study would provide useful to answering this question. It is impossible to say which newspaper was truly most accurate, although La Presse provided the most coverage as well as some of the most varying coverage and criticism, this does not equate to accuracy. Given the nature of mainstream news-media, as highlighted by most of the literature reviewed earlier in this work, I would argue that there is a disconnect between the public and media discourses, as media uses certain kinds of language (i.e. 'new racism') or misrepresents and under-represents certain populations ( $\mathrm{Li}, 2001$; Mahtani, 2001). While it is not necessarily impossible for a mainstream 
newspaper to report accurately on public discourses surrounding the issue of reasonable accommodations, they will generally portray a one-sided image that is representative of Western, male-dominated, 'white', Christian, heterosexual ideals (Jiwani, 2005).

The Bouchard-Taylor Commission was a very recent occurrence, and hence the surrounding media discourse is also recent and as a result there is currently a lack of literature on the subject of how the reasonable accommodations debate played out as well as how newcomers have been affected. This has left me forced to make theoretical linkages based on an incomplete literature review. There is no question that additional investigation into this subject is required, as it could help generate greater understanding between the dominant and immigrant groups in the province.

Content analyses of different forms of media coverage as they pertain to the debate regarding reasonable accommodations, and the integrations of immigrants more generally, could help show how particular stereotypes are being propagated in part by the media, which for many Québécois living outside of the major-immigrant receiving centres, is one of the key formats through which they gain understanding of this issue. In addition, both quantitative and qualitative research must be done to comprehend how such stereotyping affects the lives of newcomers in terms of their ability to integrate socially, culturally, and economically. What I have learned here is that stereotyping of certain ethnic groups is taking place in the province, both in the public and media discourses. One negative stereotype which has been found in this study is that at least a portion of the population and news print-media find that immigrants are not successfully integrating, either willingly or not. In order to eliminate this problem it is necessary to understand how much stereotyping plays a role in one's ability to integrate or want 
to integrate if we are to create better relations between the native-born population and newcomers.

Based on Fairclough's (1995) approach and Li's (2001) theory, research should be conducted in the province to see where the population is obtaining its information in regard to newcomers as well as how accurate they view such information to be. It would prove useful to know how critical the public is of the information it obtains through the media, and to see if the public accurately analyses the social and historical context through which this information is generated. It has been shown in various studies, some included in the literature review section of this paper, that the media does indeed have the power to influence public discourse through the promotion of stereotypes, misinformation and underrepresentation of minority groups. What would be useful would be to know to what extent media can do this, and which populations interpret media in what kind of ways.

The reasonable accommodations debate in the format undertaken in the Bouchard-Taylor Commission could serve as a potential model for future public forums regarding matters of reasonable accommodation, and it should be understood where improvements can be made to avoid overt hate speech, "new racism" (Li, 2001) and further "othering' of immigrants. Media discourses which reinforce dominant conceptions of the nation, and who belongs, must be understood if we are to change them for the better of all. The Bouchard-Taylor Commission was supposed to take on the role of a democratic forum where dissident voices could challenge the dominant discourse and help form a new and more inclusive society (Québec, 2008). I think however, that the media discourse only helped reinforce more exclusionary concepts of the Québec nation, where ‘others' are still prohibited from reshaping the dominant discourse. 


\section{Appendix}

List of Newspaper Articles Reviewed

\section{The Gazette}

Heinrich, J. (2007, Sept. 12). Feet washing and video games; Wide-ranging topics at the accommodation hearing Series: Identities. The Gazette, p. A3

Heinrich, J. (2007, Sept. 13). Rouyn-Noranda's diversity surprises; Original algonquins now minority. From Moroccan Muslims to Afro-Latino from Colombia, locals flock to have their say. The Gazette, p. A10

Heinrich, J. (2007, Sept. 14). Man in a chair decries isolation; All religion based on superstition, he says. Newcomers should become 'Québécois like me'. The Gazette, p: A14

Heinrich, J. (2007, Sept. 19). Old stock has its say; Accommodation hearings visit the North Shore. The Gazette, p. A3

Heinrich, J. (2007, Sept. 20). Flood of immigrants feared; Hearings in Saguenay. Secular society, Roman Catholic heritage in peril, Taylor-Bouchard commission told. The Gazette, p. A8

Heinrich, J. (2007, Sept. 21). Fear of other values 'visceral,' hearings told: Reasonable accommodation. 'The founding people have become third-class citizens,' Saguenay man laments. The Gazette, p. A8

Heinrich, J. (2007, Sept. 25). Laurentian residents vent anger with Hasidim; St. Jérome session becomes platform for bashing distinctive Orthodox sect. The Gazette, p. A12

Heinrich, J. (2007, Sept. 26). Commission hears of disowned daughter; Hindu family cited in scathing attack on how immigrants are treated. The Gazette, p. A3

Heinrich, J. (2007, Sept. 27). Lone voice of Jewry speaks up for attacked Hasidim; 'They're quiet ... so what do people have against them?' The Gazette, p. A8

Laws won't solve our identity crisis (2007, Sept. 29). The Gazette, p. A1

Heinrich, J. (2007, Oct. 2). A chorus of resentment in Rimouski; Reasonable accommodation hearing. But other participants urge tolerance, saying we're richer for new arrivals. The Gazette, p. A9

Heinrich, J. (2007, Oct. 3). Gays in small towns still struggle for rights; Religious extremism a new threat, hearing told. The Gazette, p. A8 
Heinrich, J. (2007, Oct. 4). Global villagers show up for accommodation roadshow; Immigrants, relatives speak. 'It's not like it was; it's something joyful'. The Gazette, p. A9

Heinrich, J. (2007, Oct. 5). 'Best of both worlds,' English Gasp teen tells commission; Language, religion accommodated. Jewish father-daughter team talk of harmony, call for end to linguistic school boards. The Gazette, p. A7

Heinrich, J. (2007, Oct. 24). Hérouxville councillor among friends at hearing; 'Reasonable accommodation' commission. Man who drafted town's controversial 'code of life' basks in allies' praise but gets harsh words, too. The Gazette, p. A8

Headlines; You might have missed this week (2007, Oct. 27). The Gazette, p. B5

Heinrich, J. (2007, Oct. 29). Islamic communities' diversity on display. The Gazette, p. A8

Heinrich, J. (2007, Oct. 30). Anti-Semitic rant gets short shrift; Reasonable accommodation hearing. Media frenzy has distorted reality, Quebec City Muslims contend. The Gazette, p. A8

Dougherty, K. and Authier, P. (2007, Oct. 31). Bertrand drops the gloves; Rips Koivu's lack of French fluency. Fears Montreal will become mostly English. The Gazette, p. A3

Dougherty, K. (2007, Nov. 1). Catholic roots worth keeping, ex-priest says; Louis ONeill speaks at accommodation commission. The Gazette, p. A10

Dougherty, K. (2007, Nov. 2). 'Here, it works like this'; Accommodation hearings in Beauce. Newcomers must conform, mayor insists. The Gazette, p. A8

Heinrich, J. (2007, Nov. 6). Don't look to Drummondville for final word on reasonable accommodation; Bouchard-Taylor open-mike session brings out wide diversity of opinion on immigrants and identity. The Gazette, p. A9

Heinrich, J. (2007, Nov. 15). Mother considers teachers in hijabs a threat; Concerned over 'bath of cultures'. Accommodation hearings continue in Laval. The Gazette, p. A7

Heinrich, J. (2007, Nov. 23). Muslims worry about 'tarnished' image; Rein in 'preachers of hate,' commission told. The Gazette, p. A8

Hustak, A. (2007, Nov. 26). Quebecers don't have to bicker, a child tells adults; Reasonable accommodation forum. But workshops hear that immigrants face bigger obstacles than language. The Gazette, p. A8

Heinrich, J. (2007, Nov. 29). Sikhs want rules bent, hearing told; Exemptions described as 'only way'. Commission also hears jab at Orthodox Jews. The Gazette, p. A8

Mennie, J. (2007, Dec. 11). Moral commitment document doesn't mention our problems; "Information on poverty and lack of access to health care might be useful." The Gazette, p. A4 
Heinrich, J. (2007, Dec. 12). Duceppe warns of 'too permissive' changes. The Gazette, p. A3

Heinrich, J. (2007, Dec. 13). Freedoms essential, Jews say; Bouchard-Taylor. B'nai Brith service organization calls for more accommodation. The Gazette, p. A1

Heinrich, J. (2007, Dec. 13). Church gave Quebec a lot, cardinal says; Turcotte distances himself from primate who apologized for 'errors'. The Gazette, p. A4

Heinrich, J. (2007, Dec. 14). Don't deprive children of religious education. The Gazette, p. A8

\section{Le Soleil}

Giroux, R. (2007, Sept. 12). Commission sur les accommodements raisonnables: Le débat religieux à l'avant-scène. Le Soleil, p. 7

Paradis, S. (2007, Sept. 19). Commission sur les accommodements raisonnables: Un témoin expulsé après avoir traité de "rétrograde" la religion musulmane. Le Soleil, p. 28

Cliche, J.-F. (2007, Sept. 20). Commission Bouchard-Taylor: Vers une participation monstre à Québec. Le Soleil, p. 9

Cliche, J.-F. (2007, Sept. 20). Commission Bouchard-Taylor: L'intégration, "oui, mais..." Le Soleil, p. 9

Cliche, J.-F. (2007, Sept. 21). Commission Bouchard-Taylor: Le maire de Saguenay prône la préséance du catholicisme; La consultation populaire a ses défauts. Le Soleil, p. 5

Cliche, J.-F. (2007, Sept. 21). Commission Bouchard-Taylor: Le maire de Saguenay prône la préséance du catholicisme; Jean Tremblay se porte à la défense de l'Église dans les institutions québécoises. Le Soleil, p. 4

Thériault, C. (2007, Oct. 3). Accommodements raisonnables: Le commissaire Bouchard parle de "l'école de Rimouski". Le Soleil, p. 20

Gagné, G. (2007, Oct. 4). La Commission Bouchard-Taylor à Bonaventure: Des Gaspésiens de toutes origines, un même message. Le Soleil, p. 30

Cliche, J.-F. (2007, Oct. 17). Commission Bouchard-Taylor: Propos surprenants tenus à Longueuil. Le Soleil, p. 9

Cliche, J.-F. (2007, Oct. 18). Offensive laïque: Le maire de Huntingdon s'oppose aux signes religieux dans les édifices publics. Le Soleil, p. 6 
Cliche, J.-F. (2007, Oct. 25). Accommodements raisonnables: Le conseiller de Hérouxville pris à partie. Le Soleil, p. 8

Cliche, J.-F. (2007, Oct. 25). Accommodements raisonnables: En bref; Commission scolaire pour la laïcité. Le Soleil, p. 8

Cliche, J.-F. (2007, Oct. 25). Accommodements raisonnables: "La religion ne peut pas être que privée" - L'évêque de Trois-Rivières. Le Soleil, p. 9

Cliche, J.-F. (2007, Oct. 25). Accommodements Raisonnables: En bref; Participation monstre. Le Soleil, p. 8

Cliche, J.-F. (2007, Oct. 26). Accommodements raisonnables: La "clause nonobstant" appelée en renfort. Le Soleil, p. 16

Cliche, J.-F. (2007, Oct. 30). Accommodements raisonnables: Le fantôme de Lévesque. Le Soleil, p. 3

Cliche, J.-F. (2007, Oct. 30). Accommodements raisonnables: Ras-le-bol musulman; Appel à la tolérance de membres du Centre culturel islamique de Québec devant la commission BouchardTaylor. Le Soleil, p. 2

Cliche, J.-F. (2007, Oct. 31). La solution dans la religion; Le cardinal Marc Ouellet prône un retour aux valeurs catholiques. Le Soleil, p. 6

Cliche, J.-F. (2007, Oct. 31). Love-in interculturel. Le Soleil, p. 7

Cliche, J.-F. (2007, Nov. 1). Accommodements raisonnables: Plaidoyer pour l'immigration; Selon le maire suppléant, Jacques Joli-Coeur, l'avenir économique de Québec dépend des nouveaux arrivants. Le Soleil, p. 7

Dion-Viens, D. (2007, Nov. 5). Commission Bouchard-Taylor: Un ado de 14 ans transmet le message des jeunes. Le Soleil, p. 11

Cliche, J.-F. (2007, Nov. 27). Accommodements raisonnables: Distinguer doctrine et interprétation; La Cour suprême a ouvert une boîte de Pandore avec l'affaire du kirpan, affirment des enseignants. Le Soleil, p. 8

Cliche, J.-F. (2007, Nov. 27). Accommodements raisonnables: "Quel malaise?" demande Louis Balthazar. Le Soleil, p. 8

Cliche, J.-F. (2007, Nov. 28). Des immigrants expriment leur colère. Le Soleil, p. 18

Cliche, J.-F. (2007, Nov. 29). Commission Bouchard-Taylor: Les sikhs victimes de "malentendus". Le Soleil, p. 12 
Cliche, J.-F. (2007, Nov. 29). Accommodements raisonnables: La facilité croît avec l'usage. Le Soleil, p. 13

Cliche, J.-F. (2007, Nov. 30). Commission Bouchard-Taylor: Les critiques les plus sévères; Les citoyens anglophones n'ont pas mâché leurs mots envers les commissaires. Le Soleil, p. 13

Cliche, J.-F. (2007, Nov. 30). Commission Bouchard-Taylor: Une définition différente de l'émancipation; Des musulmanes dénoncent le féminisme obtus de certains Québécois. Le Soleil, p. 12

Cliche, J.-F. (2007, Dec. 11). Les syndicats réclament une stricte laïcité; Le SFPQ craint que le port de signes sacrés ne compromette la neutralité des institutions publiques. Le Soleil, p. 11

Cliche, J.-F. (2007, Dec. 11). La primauté du droit sert tout le monde. Le Soleil, p. 11

Cliche, J.-F. (2007, Dec. 12). Accommodements raisonnables: Reconnaissance des diplômes; Les ordres professionnels plaident l'innocence. Le Soleil, p. 11

Cliche, J.-F. (2007, Dec. 12). Accommodements raisonnables: Duceppe ouvert aux signes religieux dans la fonction publique. Le Soleil, p. 11

Cliche, J.-F. (2007, Dec. 12). Accommodements raisonnables: Lisée veut lier le droit de vote à la connaissance du français. Le Soleil, p. 11

Gagné, J.-S. (2007, Dec. 13). Commission Bouchard-Taylor: Les Roumains de Québec ne jugent pas utile d'intervenir. Le Soleil, p. 8

Une loi 101 plus muscle; Pauline Marois a réaffirmé cette volonté devant la Commission Bouchard-Taylor (2007, Dec. 15). Le Soleil, p. 8

\section{La Presse}

Touzin, C. (2007, Sept. 11). Commission sur les accommodements raisonnable: Bouchard fait son mea-culpa. La Presse, p. A10

Ouimet, M. (2007, Sept. 12). Chronique: Ici Radio Bouchard. La Presse, p. A9

Touzin, C. (2007, Sept. 12). La Commission reçoit ses premiers mémoires. La Presse, p. A8

Marissal, V. (2007, Sept. 13). Chronique: Le "freak show". La Presse, p. A7

Touzin, C. (2007, Sept. 13). Commission sur les accommodements raisonnables: Des talibans aux autochtones en Abitibi. La Presse, p. A7

Boisvert, Y. (2007, Sept. 14). Avant d'enterrer la Commission. La Presse, p. A8 
Petrowski, N. (2007, Sept. 15). Chronique: Portrait de famille. La Presse, p. Arts et Spectacles 2

Touzin, C. (2007, Sept. 19). Commission sur les accomodements raisonnables à Sept-îles:

Gérard Bouchard réprimande un citoyen. La Presse, p. A15

Touzin, C. (2007, Sept. 20). Commission sur les accommodements raisonnables: Humour et atmosphère détendue à Saguenay. La Presse, p. A15

Touzin, C. (2007, Sept. 21). Commission Bouchard-Taylor à Saguenay: Le maire affirme ses valeurs religieuses. La Presse, p. A9

Touzin, C. (2007, Sept. 25). Accommodements raisonnables: Les juifs hassidiques dérangent à Saint-Jérôme. La Presse, p. A10

Touzin, C. (2007, Sept. 26). Le Québec "intègre mal" ses immigrés: Les structures d'accueil québécoises montrées du doigt à la commission Bouchard-Taylor. La Presse, p. A10

Touzin, C. (2007, Sept. 27). Commission sur les accommodements raisonnables: "Il ne faut pas attribuer toutes les choses que l'on considère horribles à l'islam ". La Presse, p. A5

Boisvert, Yves (2007, Oct.14). Accommodements raisonnables Chronique: De la difficulté de féliciter Jean Charest. La Presse, p. A6

Touzin, C. (2007, Oct. 16). Accommodements raisonnables: La Commission croule sous les mémoires à Longueuil. La Presse, p. A10

Touzin, C. (2007, Oct. 16). Port du voile; "Ça vient nous chercher un peu", concède Gérard Bouchard. La Presse, p. Al1

Touzin, C. (2007, Oct. 17). Accommodements raisonnables: Et la numérologie? La Presse, p. A10

Touzin, C. (2007, Oct. 18). Sortie remarquée du maire Stéphane Gendron. La Presse, p. A8

Beauchemin, M. (2007, Oct. 31). Le cardinal Ouellet à la commission Bouchard-Taylor: Le Québec "mûr" pour l'évangélisation. La Presse, p. A12

Perreault, L.-J. (2007, Nov. 16). Commission Bouchard-Taylor: Des employeurs refusent d'embaucher des musulmans. La Presse, p. A8

Perreault, L.-J. (2007, Nov. 21). La Commission Bouchard-Taylor à Montréal: Des immigrés se vident le coeur. La Presse, p. A8 
Touzin, C. and Perreault, L.-J. (2007, Nov. 26). La Commission à Montréal: Bouchard-Taylor: Mythes et Réalités. La Presse, p. A2

Perreault, L.-J. (2007, Nov. 27). Bouchard-Taylor à Montréal: La décision sur le port du kirpan cause encore des ramous; "Sans règles claires, c'est l'anarchie". La Presse, p. A6

Croteau, M. (2007, Nov. 28). Bouchard-Taylor à Montréal: Des participants craignent la politisation du débat. La Presse, p. A2

Perreault, L.-J. (2007, Nov. 28). Bouchard-Taylor à Montréal: Dispense d'Halloween et plats végétariens; Les dẹmandes d'accommodement ne sont pas une source de conflit dans les écoles multiethniques montréalaises, assurent les commissions scolaires. La Presse, p. A2

Perreault, L.-J. (2007, Nov. 29). Bouchard-Taylor à Montréal: Pas de kirpan, pas de crucifix; Des sikhs demandent que l'on affiche dans les lieux publics tous les symboles religieux ou aucun. La Presse, p. A22

Croteau, M. (2007, Nov. 30). Bouchard-Taylor à Montréal: Les anglophones appellent à la tolérance. La Presse, p. A12

Ouimet, M. (2007, Dec. 11). Bouchard-Taylor la dernière ligne droite Chronique: C'est la faute au voile. La Presse, p. A7

Perreault, L.-J. (2007, Dec. 11). Bouchard-Taylor la dernière ligne droite: Un devoir de réserve élargi; Le Syndicat de la fonction publique suggère d'interdire aux employés de l'État d'afficher leur appartenance religieuse. La Presse, p. A6

Croteau, M. (2007, Dec. 12). Bouchard-Taylor la dernière ligne droite: Les participants se font plus rares. La Presse, p. A8

Perreault, L.-J. (2007, Dec. 13). Bouchard-Taylor la dernière ligne droite: On n'en fait pas assez, plaident des représentants juifs. La Presse, p. A5

Perreault, L.-J. (2007, Dec. 14). Commission Bouchard-Taylor: Les ordres professionnels ont besoin d'un remède muscle. La Presse, p. A13

Perreault, L.-J. (2007, Dec. 15). Marois veut modifier la loi 101 et la Charte des droits. La Presse, p. A12 


\section{Bibliography}

Bauder, Harald (2008). Immigration Debate in Canada: How Newspapers Reported, 19962004. Journal of International Migration and Integration, 9(3), pp. 289-310.

Bouchard, Gérard (1999). La nation québécoise au future et au passé. VLB, Montréal.

Bouchard, Gérard and Charles Taylor (2008). Building the Future: A Time for Reconciliation. Gouvernement du Québec.

Bosset, Pierre (2005). Reflections on the Scope and Limits of the Duty of Reasonable Accommodation in the Field of Religion. Comite pour la protection de la jeunesse, Saint-Lazarre, Québec.

Cisneros, J. David (2008). Contaminated Communities: The Metaphor of 'Immigrant as Pollutant' in Media Representation of Immigration. Rhetoric \& Public Affairs, 11(4), pp. 569-602.

Citizenship and Immigration Canada (2005a). Recent Immigrants in Metropolitan Areas: Canada April 2005. Retrieved from http://www.cic.gc.ca/English/pdf/researchstats/2001-canada.pdf

Citizenship and Immigration Canada (2005b). Recent Immigrants in Metropolitan Areas: Montreal April 2005. Retrieved from http://www.cic.gc.ca/English/pdf/researchstats/2001-montreal.pdf

Cohen, Stanley (1972). Folk Devils and Moral Panics: The Creation of Mods and Rockers. MacGibbon and Kee, London.

Commission de consultation sur les pratiques d'accommodement reliées aux differences Culturelles (2010). Retrieved from $h \mathrm{htp} / / / \mathrm{www}$.accommodements.qc.ca/index-en.html

Cresswell, John W. (2009). Research Design: Qualitative, Quantitative, and Mixed Methods Approaches. Thousand Oaks, CA: Sage Publications.

Dunn, Brian (1998). Two ways to measure Québec: buyers would prefer a single readership Study, but having two isn't all bad. Marketing Magazine, 103(15), pp. 18.

Esses, Victoria M., John F. Dovidio, Lynne M. Jackson, and Tamara L. Armstrong (2001). The Immigration Dilemma: The Role of Perceived Group Competition, Ethnic Prejudice, and National Identity. Journal of Social Issues, 57(3), pp. 389-412.

Fall, Khadiyatoulah and Georges Vignaux (2008). Images de l'autre et de soi: Les accommodements raisonnables entre préjugés et réalité. Les Presses de l'Université de Laval, Québec. 
Fairclough, Norman (1995). Media Discourse. New York: E. Amold.

Foucault, Michel (1978). The History of Sexuality, Volume I. Pantheon Books, New York.

Greer, Chris and Yvonne Jewkes (2005). Extremes of Otherness: Media Images of Social Exclusion. Social Justice, 32(1), pp. 20-31.

Grondin, Chantal (2007). Knowledge of Official Languages Among New Immigrants: How Important Is It in the Labour Market? 2005. Statistics Canada, Ottawa.

Hamilton, Graeme (2002, April 17). Boy with Sikh ceremonial dagger may return to school: Judge sees no danger. National Post, pp. A4.

Helly, Denise (2004). Are Muslims Discriminated Against in Canada Since September 2001 ? Journal of Canadian Ethnic Studies, 36(1), pp. 24-47.

Kelley, Ninette and Michael Trebilcock (2000). The Making of the Mosaic: A History of Canadian Immigration Policy. Toronto: University of Toronto Press.

Jiwani, Yasmin (2005). The Great White North Encounters September 11: Race, Gender, and Nation in Canada's National Daily, The Globe and Mail. Social Justice, 32(4), pp. 50-68.

$\mathrm{Li}$, Peter (2001). The Racial Subtext in Canada's Immigration Discourse. Journal of International Migration and Integration, 2(1), pp. 77-97.

Liaw, Kao-Lee (2007). "Problematic post-landing interprovincial migration of the immigrants in Canada." SEDAP Research Program. McMaster University.

Mahtani, Minelle (2001). Representing Minorities: Canadian Media and Minority Identities. Canadian Ethnic Studies, 33(3), pp. 99-133.

Mayring, Philipp (2000). Qualitative Content Analysis. In Flick, Uwe; Von Kardorff, Ernst; and Steinke, Ines (Eds.) A Companion to Qualitative Research. Thousand Oaks, CA: Sage Publications.

McAndrew, Marie (2010). The Muslim Community and Education in Quebec: Controversies And Mutual Adaptation. Journal of International Migration and Integration, Published online: January 23, 2010. Retrieved from http://www.metapress.com.ezproxy.lib.ryerson.ca/content/2r501586775v3315/fulltext.ht $\underline{\mathrm{mll}}$

Nieguth, Tim, and Aurelie Lacassagne (2009). Contesting the Nation: Reasonable Accommodation in Rural Quebec. Canadian Political Science Review, 3(1), pp. 1-16.

Ouimet, Michele (2006, November 9). Short, libido et accommodement. La Presse, pp. A14. 
Québec, Gouvernement du (1990). Vision: A policy statement on immigration and integration. Ministère des Communautés culturelles et de l'Immigration du Québec.

Québec, Gouvernement du (2008). Commission de consultation sur les pratiques d'accommodement reliées aux differences culturelles. Retrieved from: http://www.accommodements.qc.ca/index-en.html

Québec, Gouvernement du (2009). Fiche synthèse sur l'immigration au Québec-Année 2008. Ministère de l'Immigration et des Communautés culturelles du Québec.

Québec, Gouvernement du (March 2009). Tableaux sur l'immigration permanent au Québec 2004-2008. Ministère de l'Immigration et des Communautés culturelles du Québec.

Sutherland, Anne (2006, November 16). Let male police officers deal with Hasidic men, cops told. The Gazette, pp. Al.

Thomas, Eric (1992). Canadian Broadcasting and Multiculturalism: Attempts to Accommodate Ethnic Minorities. Canadian Journal of Communication, 17(3), pp. 281-300.

Thompson, Elizabeth (2006, March 3). OK in schools: Religious freedom cited as Montreal Board's ban in quashed. The Gazette, pp. Al.

Todd, Sharon (1998). Veiling the 'Other', Unveiling Our 'Selves': Reading Media Images of The Hijab Psychoanalytically to Move Beyond Tolerance. Canadian Journal of Education, 23(4), pp. 438.

Wortley, Scot (2009). Introduction. The Immigrant-Crime Connection: Competing Theoretical Perspectives. Journal of International Migration and Integration, 10(4), pp. 349-358. 